\title{
Chaperone activity of serine protease HtrA of Helicobacter pylori as a crucial survival factor under stress conditions
}

\author{
Urszula Zarzecka ${ }^{1,2}$, Aileen Harrer ${ }^{1}$, Anna Zawilak-Pawlik³ ${ }^{3}$ Joanna Skorko-Glonek ${ }^{2}$ and Steffen Backert ${ }^{*}$ (D)
}

\begin{abstract}
Background: Serine protease HtrA exhibits both proteolytic and chaperone activities, which are involved in cellular protein quality control. Moreover, HtrA is an important virulence factor in many pathogens including Helicobacter pylori, for which the crucial stage of infection is the cleavage of E-cadherin and other cell-to-cell junction proteins.

Methods: The in vitro study of $\mathrm{H}$. pylori $\mathrm{HtrA}\left(\mathrm{HtrA}_{H p}\right)$ chaperone activity was carried out using light scattering assays and investigation of lysozyme protein aggregates. We produced H. pylori $\triangle$ htrA deletion and HtrA $A_{H p}$ point mutants without proteolytic activity in strain N6 and investigated the survival of the bacteria under thermal, osmotic, acidic and general stress conditions as well as the presence of puromycin or metronidazole using serial dilution tests and disk diffusion method. The levels of cellular and secreted proteins were examined using biochemical fraction and Western blotting. We also studied the proteolytic activity of secreted HtrA $A_{H p}$ using zymography and the enzymatic digestion of $\beta$-casein. Finally, the consequences of E-cadherin cleavage were determined by immunofluorescence microscopy.
\end{abstract}

Results: We demonstrate that $\mathrm{HtrA}_{H p}$ displays chaperone activity that inhibits the aggregation of lysozyme and is stable under various $\mathrm{pH}$ and temperature conditions. Next, we could show that N6 expressing only HtrA chaperone activity grow well under thermal, $\mathrm{pH}$ and osmotic stress conditions, and in the presence of puromycin or metronidazole. In contrast, in the absence of the entire htrA gene the bacterium was more sensitive to a number of stresses. Analysing the level of cellular and secreted proteins, we noted that $H$. pylori lacking the proteolytic activity of HtrA display reduced levels of secreted HtrA. Moreover, we compared the amounts of secreted HtrA from several clinical H. pylori strains and digestion of $\beta$-casein. We also demonstrated a significant effect of the HtrA $\mathrm{A}_{H p}$ variants during infection of human epithelial cells and for E-cadherin cleavage.

Conclusion: Here we identified the chaperone activity of the HtrA $\mathrm{H}_{\mathrm{p}}$ protein and have proven that this activity is important and sufficient for the survival of $\mathrm{H}$. pylori under multiple stress conditions. We also pinpointed the importance of HtrA $\mathrm{A}_{H p}$ chaperone activity for $\mathrm{E}$ - cadherin degradation and therefore for the virulence of this eminent pathogen.

Keywords: HtrA, Chaperone, Protease, Helicobacter pylori, E- cadherin, Virulence factor, Protein quality control system, Stress endurance, Secreted proteins

\footnotetext{
* Correspondence: steffen.backert@fau.de

${ }^{1}$ Division of Microbiology, Department of Biology,

Friedrich-Alexander-University Erlangen-Nürnberg, Erlangen, Germany

Full list of author information is available at the end of the article
}

(c) The Author(s). 2019 Open Access This article is distributed under the terms of the Creative Commons Attribution 4.0 International License (http://creativecommons.org/licenses/by/4.0/), which permits unrestricted use, distribution, and reproduction in any medium, provided you give appropriate credit to the original author(s) and the source, provide a link to the Creative Commons license, and indicate if changes were made. The Creative Commons Public Domain Dedication waiver (http://creativecommons.org/publicdomain/zero/1.0/) applies to the data made available in this article, unless otherwise stated. 


\section{Background}

Helicobacter pylori is a helical-shaped Gram-negative bacterium, that infects more than half of the human world population [1]. Colonization of the gastroduodenal mucosa by $H$. pylori can lead to chronic gastritis and eventually to the development of peptic ulcers, and represents an important risk factor for malignant alterations such as gastric cancer [2]. To establish a persistent infection, the bacteria must withstand a variety of stressful conditions in the hostile environment of the human stomach. These include heat shock, oxidative, osmotic and acidic stresses, as well as treatment with pharmaceuticals. To persist in this particular niche, $H$. pylori have developed sophisticated stress response systems that allow survival and propagation of the bacteria. H. pylori can survive the transient exposure to extreme acid conditions before adherence and growth on the gastric epithelium [3]. For this purpose, H. pylori express a specialized urease enzyme locally buffering the $\mathrm{pH}$, which is crucial for survival and adaptation of the bacteria in a changing environment [3]. The $\mathrm{pH}$ of the gastric lumen in humans is variable and can reach even $\mathrm{pH}$ $\sim 1$, but the $\mathrm{pH}$ near the gastric surface is significantly higher and may be close to neutral [4]. For Gramnegative organisms, including $H$. pylori, the $\mathrm{pH}$ in the periplasm is most crucial for bacterial survival and growth. Under in vitro conditions in the laboratory, $H$. pylori propagate best at neutral $\mathrm{pH}$, but under acidic situations, they increase their periplasmic $\mathrm{pH}$ using a specialized mechanism, so that the bacterium can be regarded as acid-tolerant neutralophile [4].

H. pylori effectively secretes proteins into the extracellular environment, which can be involved in various pathogen-host interactions. This secretome has been studied by mass spectrometry and other techniques, and comprises up to about 125 reported proteins, most notably VacA [5], UreB [6], GGT [7], NapA [8], GroEL [9] and serine protease HtrA (high temperature requirement A) [10]. The proper transport of these proteins across the two bacterial membranes is therefore crucial for the bacteria and requires specific control mechanisms. For example, bacteria subjected to adverse environmental conditions may accumulate damaged proteins. Misfolded polypeptides induce the so-called protein quality control system, comprising chaperones and proteases, whose task is to refold proteins or remove them from a cell by degradation. Depending on the mechanism of action, chaperones can be divided into two major categories, folder and holder chaperones. The folder chaperones (e.g. DnaK and GroEL) are ATP-dependent and participate in the folding and activation of proteins inactivated by certain stress factor, restoring their functionality to the correct conformation and biological properties [11, 12]. On the other hand, holder chaperones (e.g. Ibp and ClpB) can bind to misfolded proteins (independent of ATP), form stable complexes with them and prevent their aggregation; however, this kind of chaperone cannot actively restore the native protein conformation [13, 14]. All bacterial proteins are initially synthesized in the cytoplasm; however, a certain fraction is destined for export to the cellular envelope or extracellular space. Transport of the secreted proteins to the secretory systems and their proper folding at the final destination also requires assistance of chaperone proteins $[15,16]$. The bacterial periplasm is particularly predisposed to damage by external factors due to the low selectivity of the outer membrane. Therefore, the extra-cytoplasmic protein quality control system is important for a bacterial cell to ensure proper protein folding and survive stress. The key components of this system are members of the HtrA family of serine proteases. It has been demonstrated that the presence of functional HtrA proteins is necessary for various bacterial species to withstand stressful conditions, such as heat shock or oxidative stress [17-19]. Several known bacterial HtrA homologs exhibit an additional chaperone-like activity, important for the housekeeping roles of these proteins. For example, the presence of the proteolytically inactive Escherichia coli HtrA HtrA $E_{E c}\left(\operatorname{DegP}_{E c}\right)$ variant (S210A, but retaining its chaperone function) is sufficient to protect $E$. coli cells from accumulation of toxic protein aggregates under heat shock conditions [20].

It has been demonstrated that HtrA is important for survival in the host and/or virulence of several bacterial pathogens such as Salmonella enterica serovar Typhimurium [21], Listeria monocytogenes [22], Klebsiella pneumoniae [23] and Yersinia enterocolitica [24]. In $H$. pylori, the presence of functional $\mathrm{Htr}_{H p}$ is necessary to cross the epithelial barrier upon infection. In particular, it cleaves components of the epithelial intercellular junctions, like E-cadherin [25], claudin-8 and occludin [26]. Our very recent publications describe the importance of $\mathrm{HtrA}_{H p}$ in response of the cells to stress and biochemical properties of $\mathrm{HtrA}_{H p}$ protein $[27,28]$. In brief, $\mathrm{HtrA}_{H p}$ is important for the survival of $H$. pylori in case of exposure to certain types of stress, for example, heat shock $\left(41{ }^{\circ} \mathrm{C}\right)$, treatment with puromycin, acidic or basic $\mathrm{pH}$ (pH 5.2 and $\mathrm{pH} 7.7$ ) and ionic osmotic stressors (e.g. $\mathrm{NaCl})$ at elevated temperature $\left(39^{\circ} \mathrm{C}\right)$ [27]. Interestingly, the protease function of $\mathrm{HtrA}_{H p}$ is preserved over a wide range of $\mathrm{pH}$ values $[27,29]$.

The chaperone activity of the $\mathrm{HtrA}_{H p}$ protein is less well understood compared to its proteolytic activity [30]. Due to lack of ATP in the periplasm, HtrAs function presumably as holdases. However, there is growing evidence that the chaperone-like activity of HtrA proteins is involved in the folding and transport of the extracytoplasmic proteins, including several virulence factors. For example, secretion of filamentous hemagglutinin 
(FHA) in Bordetella pertussis is HtrA-dependent [31]. The chaperone-like activity of HtrA plays also important roles in the infection process of Campylobacter jejuni, a bacterial species closely related to $H$. pylori $[32,33]$. The interactions between $C$. jejuni and host cells depend on the chaperone activity of HtrA and bacterial binding to epithelial cells was 5-10 times reduced in the absence of HtrA [32]. The chaperone activity of HtrA alone is sufficient for the growth of $C$. jejuni at high temperature. However, when the temperature and oxygen stresses are combined, the chaperone activity is not sufficient anymore to ensure the survival of the bacterium. This observation suggests that severe stress increases the content of unfolded proteins to a point at which chaperone activity is not sufficient to prevent the accumulation of toxic protein aggregates and proteolytic activity is needed to remove the damaged proteins [34].

In the present work, we examined the importance of the HtrA chaperone for the growth of $H$. pylori under stressful conditions and with regard to the virulence of this bacterium. For a long time, studies on the chaperone activity of $\mathrm{HtrA}_{H p}$ at the cellular level were hampered by a lack of appropriate $H$. pylori $\Delta h t r A$ mutant strains. Our recent report on the construction of a mutant carrying the htrAS221A gene coding for the proteolytically inactive HtrA variant in $H$. pylori strain N6 has opened new research possibilities [28]. Using this strain, we demonstrate here that the chaperone activity of the $\mathrm{Htr}_{H p}$ protein plays important roles in the survival of bacteria under severe stress conditions, as well as its role in pathogenesis. We also characterized the chaperone-like activity of this protein in vitro and showed that $\mathrm{HtrA}_{H p} \mathrm{~S} 221 \mathrm{~A}$ efficiently prevents aggregation of a chemically denatured model substrate, lysozyme. To our knowledge, this is the first report characterizing the chaperone activity of $\mathrm{HtrA}_{H p}$ both in vivo and in vitro.

\section{Methods}

Plasmids, bacterial strains, proteins expression and purification

The strains and plasmids used in this study are listed in Table 1. All HtrA $\mathrm{A}_{H p}$ proteins were expressed and purified exactly as described previously [27]. In brief, E. coli BL21(DE3) transformed with the appropriate plasmid was used to overproduce the proteolytically inactive $\mathrm{HtrA}_{H p} \mathrm{~S} 221 \mathrm{~A}$ and $\mathrm{HtrA}_{E c} \mathrm{~S} 210 \mathrm{~A}$ variants ( $\mathrm{His}_{6}$-tagged), respectively. Bacteria were grown at $37^{\circ} \mathrm{C}$ in LuriaBertani (LB) broth supplemented with $50 \mu \mathrm{g} / \mathrm{mL}$ kanamycin or $50 \mu \mathrm{g} / \mathrm{mL}$ ampicillin to an optical density at $600 \mathrm{~nm}\left(\mathrm{OD}_{600}\right)$ 0.6-0.7. Next, $0.5 \mathrm{mM}$ isopropyl- $\beta-\mathrm{D}$ thiogalactopyranosid (IPTG) was added to induce HtrA protein expression. After lysis and clearing of the lysates by centrifugation, HtrA proteins were purified through nickel-affinity chromatography.

\section{Bacterial growth conditions}

The $H$. pylori wild-type (wt) strains and the derivatives were grown on GC agar (Oxoid) supplemented with 10\% donor horse serum (Biowest, France), protease peptone (Oxoid, Germany), $1 \%$ vitamin mix, $10 \mu \mathrm{g} / \mathrm{mL}$ vancomycin, $5 \mu \mathrm{g} / \mathrm{mL}$ trimethoprim, $8 \mu \mathrm{g} / \mathrm{mL}$ amphotericin and $10 \mu \mathrm{g} / \mathrm{mL}$ colistin. In the case of mutant H. pylori, the media were supplemented with $10 \mu \mathrm{g} / \mathrm{mL}$ kanamycin or $8 \mu \mathrm{g} / \mathrm{mL}$ chloramphenicol, respectively. Bacteria were incubated for 2 days at $37{ }^{\circ} \mathrm{C}$ in a $2.5 \mathrm{~L}$ anaerobic jar under microaerobic conditions generated by a CampyGen $^{\text {nw }}$ sachet (Oxoid, Germany). Colonies were harvested and suspended in BHI (Oxoid, Germany) or Brucella Broth (BB) medium (Sigma-Aldrich, Germany) medium. The bacteria were quantified by $\mathrm{OD}_{600}$ measurement and were normalized to 0.35 . To induce stress, serial dilutions of a bacterial suspension $(5 \mu \mathrm{L})$ were spotted onto GC agar plates containing a stress-inducing agent and grown for 6 days. The culture conditions and

Table 1 Bacterial strains and plasmids

\begin{tabular}{|c|c|c|}
\hline Strain/ plasmid & Genotype & Reference/ source \\
\hline $\mathrm{DH} 5 \mathrm{a}$ & supE44 $\Delta l a c U 169$ ( $\varphi 80$ lacZ $\Delta \mathrm{M} 1)$ hsdR17 endA1 gyrA96 thi-1 relA1 & {$[35]$} \\
\hline E. coli BL21DE3 & $\mathrm{F}^{-}$ompT hsdS $\left(r_{B}{ }^{-} m_{B}{ }^{-}\right) \mathrm{gal} \mathrm{dcm}$ & Novagen \\
\hline H. pylori 26695 & Wild-type strain & {$[36]$} \\
\hline H. pylori $J 99$ & Wild-type strain & {$[37]$} \\
\hline H. pylori G27 & Wild-type strain & {$[38]$} \\
\hline H. pylori 7.13 & Wild-type strain & [39] \\
\hline H. pylori N6 & Wild-type strain & {$[40]$} \\
\hline H. pylori N6 $\Delta h t r A$ & H. pylori N6 secAR837K $\Delta h \operatorname{trA} \mathrm{Kan}^{\mathrm{R}}$ & {$[28]$} \\
\hline H. pylori N6 $\triangle h t r A / h t r A_{N 6}$ & H. pylori N6 secAR837K $\Delta h t r A / h t r A_{N 6} C^{R}$ & {$[28]$} \\
\hline H. pylori N6 $\Delta h t r A / h t r A_{N 6}$ S221A (S/A) & H. pylori N6 secAR837K $\triangle h t r A / h t r A_{N 6}$ S221A, $\mathrm{Cm}^{\mathrm{R}}$ & {$[28]$} \\
\hline pJS17 & pQE60, htrA S210A from E.coli with C-terminal His ${ }_{6}$-tag, Amp ${ }^{R}$ & [41] \\
\hline pUZ3 & pET26b, htrAS221A from the H. pylori 26695 strain with C- terminal His ${ }_{6}$-tag, Kan $^{R}$ & {$[27]$} \\
\hline
\end{tabular}


concentration of stress agents have been described previously [27]. Briefly, we used puromycin $(2.5 \mu \mathrm{g} / \mathrm{mL})$, metronidazole $(30 \mu \mathrm{g} / \mathrm{mL})$ and various $\mathrm{pH}$ of the growth medium. The final $\mathrm{pH}$ after supplementation and sterilization of the medium was verified using the $\mathrm{pH} 5$ food tester kit (Roth, Germany) and $\mathrm{pH}$ was determined as 5.2, 5.6 and 7.7. Standard GC agar plates were prepared at $\mathrm{pH} 7.1$.

The non-ionic (175 mM sucrose) and ionic $(85 \mathrm{mM}$ $\mathrm{NaCl}$ or $32 \mathrm{mM} \mathrm{MgCl}_{2}$ ) osmolytes were added to the GC medium to induce osmotic shock. The heat shock was induced by increasing the temperature to 39 or $41{ }^{\circ} \mathrm{C}$, respectively. To assess susceptibility to oxidative stress, the disk diffusion assay was performed. For this purpose, $300 \mu \mathrm{L}$ aliquots of bacterial suspensions in BHI medium $\left(\mathrm{OD}_{600} 0.4\right)$ were spread over the entire surface of the GC agar plates to generate a lawn. Next, sterile 7 $\mathrm{mm}$ diameter disks (Whatman $3 \mathrm{~mm}$ ) were placed on the top of the agar and $5 \mu \mathrm{L}$ portions of $2 \%$ cumene hydroperoxide or $10-\mu \mathrm{L}$ portions of $30 \%$ hydrogen peroxide were added to induce oxidative stress. The plates were incubated at $37^{\circ} \mathrm{C}$ or $39^{\circ} \mathrm{C}$, and after 3 days the inhibition zones were measured. All experiments were performed at least three times.

\section{In vitro analysis of the chaperone-like activity in HtrA Light scattering assays}

The assays were performed exactly as described [42]. In brief, measurements were performed using PerkinElmer LS55 Luminescence Spectrometer. Reaction mixtures $(900 \mu \mathrm{L})$ containing $20 \mu \mathrm{M}$ lysozyme, $10 \mu \mathrm{M}$ HtrA S221A (HtrA S/A, inactive variant), $400 \mathrm{mM} \mathrm{NaCl}, 50$ $\mathrm{mM}$ HEPES pH 6.2/ 7.0 / 8.0 or $50 \mathrm{mM}$ acetate pH 5.0 were pre-incubated at various temperatures in quartz cuvettes in a thermostated cell holder to obtain proper baselines. Next, the reductant, Tris (2-carboxyethyl) phosphine (TCEP), was added to final concentrations of $20 \mu \mathrm{M}-15 \mathrm{mM}$ (specified in the legend of Fig. 1) and scattering was measured.

\section{Quantification of the lysozyme aggregates}

Assays were performed exactly as described [42]. In brief, reaction mixtures $(0.4 \mathrm{~mL})$ containing $40 \mu \mathrm{M}$ lysozyme, $20 \mu \mathrm{M}$ HtrA S/A, $400 \mathrm{mM} \mathrm{NaCl}, 50 \mathrm{mM}$ HEPES pH 6.2/ 7.0/ 8.0 or $50 \mathrm{mM}$ acetate pH 5.0 and appropriate concentrations of TCEP (specified in the legend of Fig. 2) were incubated at a temperature specified in the text. Samples $(100 \mu \mathrm{L})$ were analyzed at three-time points $(0,20$ and $60 \mathrm{~min})$. The mock control sample did not contain $\mathrm{HtrA}_{H p} \mathrm{~S} / \mathrm{A}$. The samples were immediately centrifuged at $14,000 \times \mathrm{g}$ and $4{ }^{\circ} \mathrm{C}$ for $10 \mathrm{~min}$. Pellets were dissolved in $20 \mu \mathrm{L}$ of $8 \mathrm{M}$ urea. The concentration of proteins was estimated by staining with Amino Black and spectrophotometric measurement as described [43].
As a standard, pure lysozyme with specified concentration was used.

\section{MKN-28 cell culture, $H$. pylori infection and immunofluorescence staining}

MKN-28 cells (JCRB, \#0235) were originally isolated from human gastric adenocarcinoma and represent an established polarized cell model to study the gastrointestinal barrier [44, 45]. Cells were cultured in 12-well plates with RPMI1640 medium, containing $4 \mathrm{mM}$ glutamine (Invitrogen, Karlsruhe/Germany), and 10\% FCS (Invitrogen, Karlsruhe/Germany) like was described [46, 47]. H. pylori wt strains and N6 derivatives were grown on GC agar for 2 days as described above. Next, bacteria were suspended in $\mathrm{BB}$ medium and $\mathrm{OD}_{600 \mathrm{~nm}}$ was measured. Infections were performed at a multiplicity of infection (MOI) of 100. After $6 \mathrm{~h}$ of infection, the cells were fixed and subjected to immunofluorescence staining as described [47]. Briefly, cell samples were fixed using methanol for $10 \mathrm{~min}$ at $20{ }^{\circ} \mathrm{C}$, followed by permeabilization with $0.5 \%$ Triton- X100 for $1 \mathrm{~min}$ and blocking with buffer A (1\% BSA, 0.1\% Tween20 in PBS) for $30 \mathrm{~min}$. Samples were incubated with mouse $\alpha$-E-cadherin (CD324, BD Biosciences, San Jose, CA/United States) and rabbit $\alpha-H$. pylori antibodies (Dako, Glostrup/ Denmark) for $1 \mathrm{~h}$. As secondary antibodies, FITC (fluorescein isothiocyanate)-conjugated goat anti-mouse (Thermo Fisher Scientific, Darmstadt/Germany), and Alexa Fluor 546-conjugated goat anti-rabbit (Thermo Fisher Scientific, Darmstadt/Germany) were used. Samples were analyzed using a Leica DMI4000B fluorescence microscope and different lasers (Leica Microsystems, Wetzlar/Germany). Images were obtained via LAS AF computer software (Leica Microsystems) that were optimized in brightness and contrast with ImageJ-win64 software (version 1.52n) [48].

\section{Casein zymography}

Bacterial pellets were harvested from GC agar plates and suspended in phosphate buffer saline (PBS). In addition, supernatants obtained from $H$. pylori liquid culture (BB medium supplemented with $0.2 \% \quad \beta$-cyclodextrin and cholesterol) were used in the experiment. Next, both kinds of samples were mixed with Laemmli buffer (30 $\mathrm{mM}$ Tris- $\mathrm{HCl}, \mathrm{pH} 6.8$, 5\% glycerol, $1.5 \%$ sodium dodecyl sulfate, $0.005 \%$ bromophenol blue) and loaded onto $10 \%$ SDS-PAGE gels containing $0.1 \%$ casein (Carl Roth, Germany) and electrophoresed under non-reducing conditions. In the next step, in-gel proteins were renatured by incubation of the gel in $2.5 \%$ Triton X-100 solution at room temperature for $60 \mathrm{~min}$ with gentle agitation and equilibrated overnight in the developing buffer $(50 \mathrm{mM}$ Tris- $\mathrm{HCl}, \mathrm{pH} 7.4,200 \mathrm{mM} \mathrm{NaCl}, 5 \mathrm{mM} \mathrm{CaCl}, 0.02 \%$ Brij35) at $37^{\circ} \mathrm{C}[33,46,49]$. Transparent bands of proteins with caseinolytic activity were visualized by staining with $0.5 \%$ Coomassie Blue R250 as described [50]. 

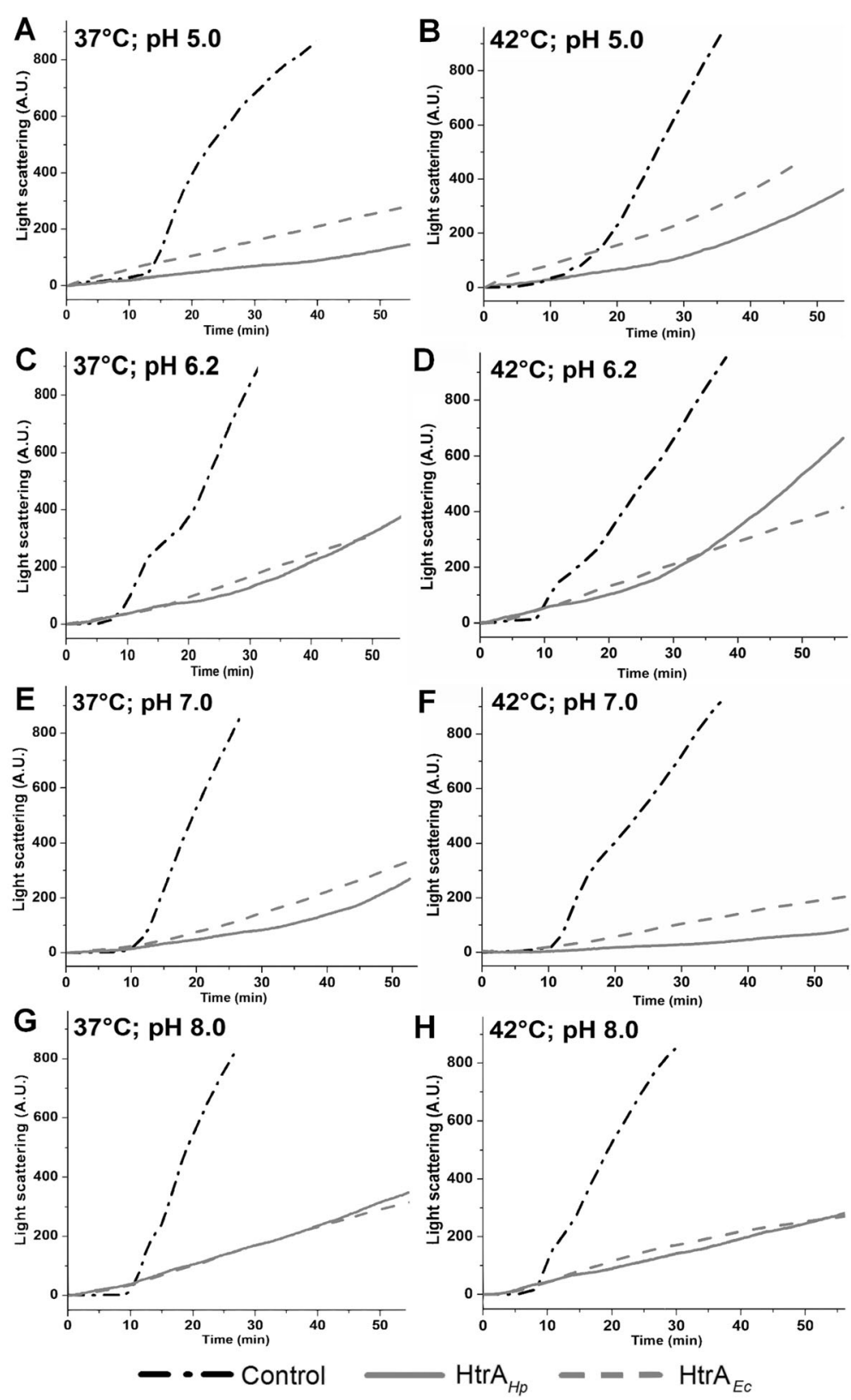

Fig. 1 Effect of $H t r A_{E C} S 210 A$ and $H \operatorname{tr} A_{H P} S 221 A$ on aggregation of lysozyme at various temperature and $p H$. The assays were performed in a spectrofluorimeter in thermostated cuvette holders at temperature and $\mathrm{pH}$ values indicated in each panel. Samples without HtrA were used as a control. The samples were prepared and analysed as described in Materials and methods. The TCEP concentration used in the assays were: $37^{\circ} \mathrm{C}(\mathbf{a}) \mathrm{pH} 5.0-15 \mathrm{mM}$ (c) pH 6.2-0.35 mM (e) pH 7.0-0.1 mM (g) pH 8.0-0.03 mM; 42 ${ }^{\circ} \mathrm{C}$ (b) pH 5.0-3.5 mM (d) pH 6.2-0.4 mM (f) pH 7.0-0.025 mM (h) pH 8.0-0.02 mM

\section{SDS-PAGE and immunoblotting}

The SDS-PAGE buffer was mixed with bacterial pellet or supernatant and boiled for $10 \mathrm{~min}$. Samples were separated by SDS-PAGE using $8,10,12$ or $15 \%$ gels. The separated proteins were stained by Coomassie Brilliant Blue (Merck) or blotted onto PVDF membrane (Carl Roth) and blocked with 5\% skim milk in TBS-T buffer (200 mM Tris pH 7.4, 1.4 M sodium chloride and 1\% Tween-20) for $30 \mathrm{~min}$ at room temperature or overnight at $4{ }^{\circ} \mathrm{C}$. The primary antibodies were incubated with membranes for $1.5 \mathrm{~h}$, followed by addition of the secondary antibody for $1 \mathrm{~h}$. Antibody detection was performed as described [46].

\section{Antibodies}

The following antibodies were used: rabbit polyclonal $\alpha$ HtrA [28]; rabbit polyclonal $\alpha$-CagA antibody (Austral Biologicals, cat. 5003-9); rabbit polyclonal $\alpha$-HP1021 

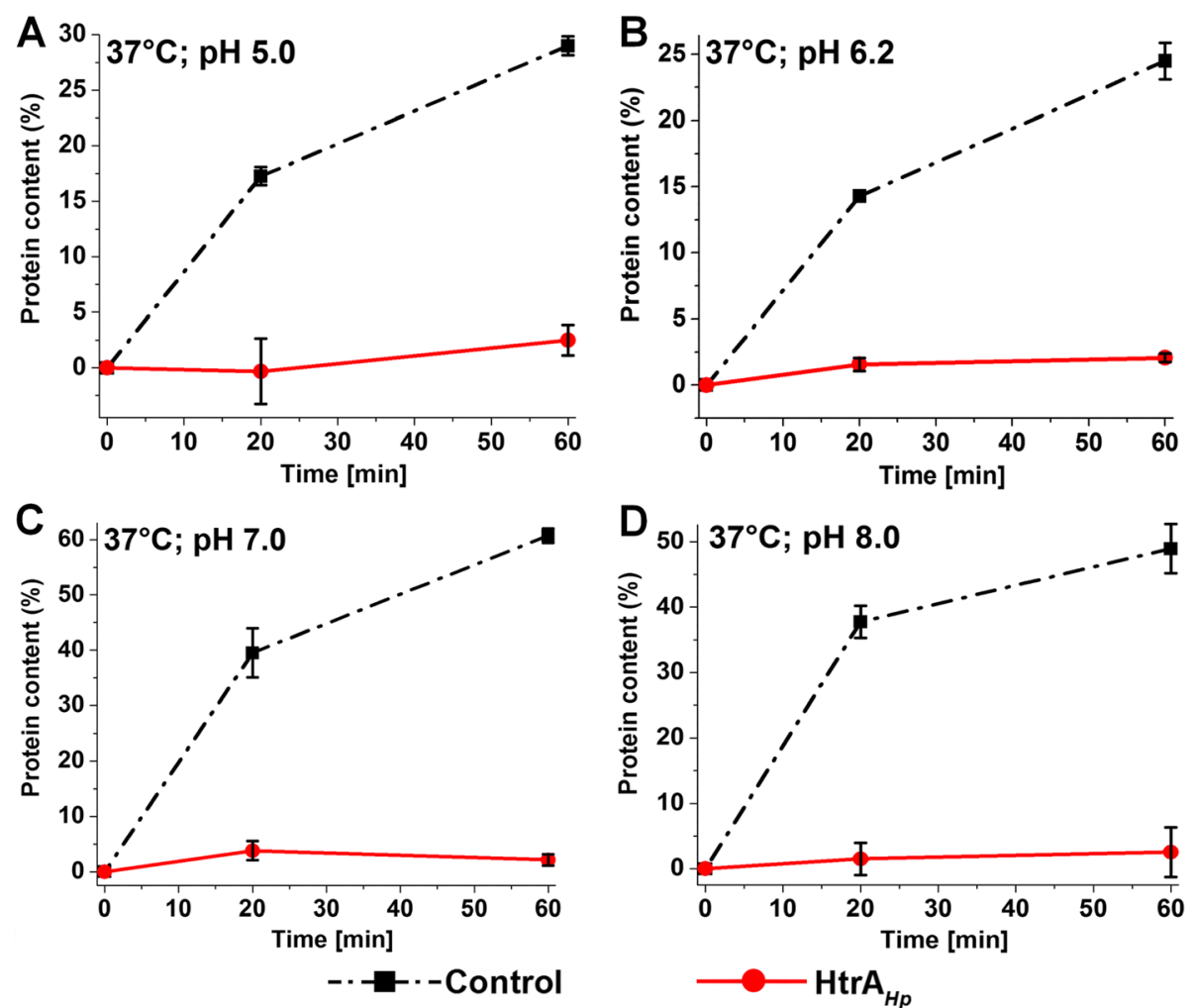

Fig. 2 Influence of $\mathrm{HtrA}_{H p} \mathrm{~S} 221 \mathrm{~A}$ (26695 strain) on the formation of large aggregates of denatured lysozyme. The graphs show the rates of formation of large lysozyme aggregates at $37^{\circ} \mathrm{C}$ and pH 5.0 (a), 6.2 (b), 7.0 (c) and 8.0 (d). Samples without HtrA were used as a control. The molar ratio HtrA/lysozyme in the samples was 1:2. TCEP concentrations used: a 46 mM; b $40 \mathrm{mM} ; \mathbf{c} 1.4 \mathrm{mM}$ and $\mathbf{d} 0.05 \mathrm{mM}$. The error bars represent the standard deviation values from three independent measurements

[51]; rabbit $\alpha$-GGT antibody [52]; rabbit $\alpha$-NapA antibody [52]; rabbit $\alpha$-UreB antibody ( $\alpha$ - HDYTIYGEELK); rabbit $\alpha$-Lon E. coli antibody (Sino Biological, cat. 40,219RP01); rabbit $\alpha-$ DnaJ $_{E}$ coli antibody (Enzo Life Sciences, cat. ADI-SPA-410); rabbit $\alpha-\mathrm{ClpB}_{E \text {. coli }}$ antibody [53]; rabbit $\alpha-\operatorname{GroEL}_{E}$. coli antibody [54]. As a secondary antibody we used goat anti-rabbit polyvalent, horseradish peroxidase-conjugated IgGs (catalogue number \#31462, Life Technologies, Darmstadt/Germany).

\section{HtrA $A_{H p}$ secretion assay}

The wild-type N6 $H$. pylori and derivatives were suspended in BB medium supplemented with cholesterol and $1 \%$ vitamin mix, $10 \mu \mathrm{g} / \mathrm{ml}$ vancomycin, $5 \mu \mathrm{g} / \mathrm{ml}$ trimethoprim, $8 \mu \mathrm{g} / \mathrm{ml}$ amphotericin and $10 \mu \mathrm{g} / \mathrm{ml}$ colistin. The $\mathrm{OD}_{600}$ was measured and adjusted to 0.3 , followed by $H$. pylori growth for $16-18 \mathrm{~h}$ under shaking at $160 \mathrm{rpm}$ and physiological temperature $\left(37^{\circ} \mathrm{C}\right)$. The bacterial pellets and supernatants were prepared by centrifugation at 5000x g for $10 \mathrm{~min}$. Next, Laemmli lysis buffer was added to the pellets. The supernatants were centrifuged at $13,000 \mathrm{x} g$ for $30 \mathrm{~min}\left(4^{\circ} \mathrm{C}\right)$ and transferred through $0.21 \mu \mathrm{m}$ sterile filters to remove entire cells and and cell debris, and treated it as described [10]. Bacterial pellets (cellular proteins) and supernatants (secreted proteins) were analysed by Western blotting.

\section{Protein secretion assay using centrifugal filters}

The $\mathrm{OD}_{600}$ of wt $H$. pylori strains N6, 26695, J99, G27 and 7.13 as well as N6 $4 h t r A$ mutants was measured and adjusted to 0.2. The bacteria were resuspended in $B B$ medium supplemented with antibiotics as described above and with $1 \%$ vitamin mix, cholesterol, and $0.1 \% \beta$ cyclodextrin and grown for $16 \mathrm{~h}$ under shaking at 160 $\mathrm{rpm}\left(37^{\circ} \mathrm{C}\right)$. The bacterial pellets and supernatants were prepared by centrifugation at $5000 \mathrm{x} \mathrm{g}$ for $10 \mathrm{~min}$. The supernatants were centrifuged at $13,000 \mathrm{x}$ g for $30 \mathrm{~min}$ $\left(4^{\circ} \mathrm{C}\right)$ and transferred through $0.21 \mu \mathrm{m}$ sterile filters as described above. In the next step, supernatants were concentrated about 18 times by Amicon Ultra $0.5 \mathrm{~mL}$ Centrifugal Filters-10 $\mathrm{K}$ and total protein concentration of the supernatant was measured by NanoDrop (Thermo Scientific). The concentration of all supernatant samples was adjusted to $80 \mu \mathrm{g} / \mu \mathrm{L}$ and Laemmli lysis buffer was added. Samples were analysed by Western blot or SDSPAGE Coomassie Brilliant Blue staining. The relative amounts of $\mathrm{HtrA}_{H p}$ secreted by several $H$. pylori strains 
were measured by densitometry of Western blot band intensities as described below. Next, the same amounts of total proteins from the supernatants were used for cleavage assays with $\beta$-casein $(8 \mu \mathrm{g}$ of $\beta$-casein per reaction). Reactions were performed in reaction buffer (50 mM HEPES $\mathrm{pH} \mathrm{7.4;} 100 \mathrm{mM} \mathrm{NaCl}$ ) for $16 \mathrm{~h}$ at $37^{\circ} \mathrm{C}$. The reactions were terminated by the addition of Laemmli lysis buffer and then resolved in 15\% SDSPAGE and analysed using densitometry. Sample without supernatant was used as mock control and this band was set as $100 \%$.

\section{Quantification of Western blot band intensities and statistics}

To quantify band intensities on immunoblots, we performed densitometric measurements using the 1DScan EX program (Scanalytics Inc., United States). The statistics One-Way Anova (Bonferroni test) approach was performed using OriginPro 8.5.1 software (OriginLab Corp., USA). Statistical significance was defined by $p \leq 0.05$ ("), $^{*}$ $p \leq 0.01{ }^{(* *)}$ ) and $p \leq 0.001{ }^{(* * *)}$.

\section{Results}

\section{$\mathrm{Htr}_{H p}$ exhibits chaperone activity}

Functional studies in E. coli and other bacteria indicate that proteins of the HtrA family do not have only proteolytic activity, but also chaperone activity [55]. In the present work, we investigated the chaperone capabilities of $\mathrm{HtrA}_{H p}$ to inhibit aggregation of unfolded proteins. To this end, we first tested under which conditions $\mathrm{HtrA}_{H p}$ exhibits chaperone activity using reduced lysozyme as a substrate. Aggregation of lysozyme was initiated chemically by using a reducing agent, which reduced disulfide bridges stabilizing the protein structure [56]. HtrA $A_{E c}\left(\operatorname{DegP}_{E c}\right)$ was used as a positive control, because chaperone activity of this HtrA homolog is best studied and was first published $[18,20]$. The process of lysozyme aggregation was monitored by light scattering measurements, a method that enables to visualize formation of aggregated protein particles in a course of time. To study the $\mathrm{pH}$ and/or temperature dependence of the $\mathrm{HtrA}_{H p}$ chaperone activity, the reactions were performed at $\mathrm{pH} 5.0,6.2,7.0$, and 8.0 , and temperatures of $37^{\circ} \mathrm{C}$ and $42^{\circ} \mathrm{C}$ (Fig. 1). Generally, significant suppression of the lysozyme aggregation by $\mathrm{Htr}_{H p}$ was observed under all tested conditions. The control chaperone, HtrA $\mathrm{A}_{E c}$ $\left(D_{e g} P_{E c}\right)$, reduced lysozyme aggregation to the similar extent. Both proteins were most efficient at neutral $\mathrm{pH}$ (7.0). To characterize the efficiency of $\mathrm{HtrA}_{H p}$ as a chaperone, we evaluated amounts of the denatured lysozyme precipitates formed in the presence/absence of $\mathrm{HtrA}_{H p}$. We found that co-incubation with $\mathrm{Htr} \mathrm{A}_{H p}$ drastically reduced the quantity of large aggregates under all tested conditions (Fig. 2). Taken together, we concluded that $\mathrm{HtrA}_{H p}$ exhibits a chaperone activity which is effective under a wide range of physiological temperatures and $\mathrm{pH}$ values.

\section{Effect of the HtrA chaperone activity on the viability of $H$. pylori under various stress conditions}

We have recently identified that lack of $h t r A$ significantly affects the survival of $H$. pylori under stressful conditions [27]. In the present study, we aimed to investigate the impact of proteolytically inactive HtrA in $H$. pylori, which will allow us to evaluate the role of chaperone activity of this protein in the bacterium. For these tests, we used $H$. pylori N6 wt and its derivatives N6 $\Delta h \operatorname{trA}(\Delta h \operatorname{tr} A), \mathrm{N} 6$ $\Delta h \operatorname{trA} / h \operatorname{tr}_{\mathrm{N} 6}$ S221A ( $\left.\Delta h \operatorname{trA} / h \operatorname{trA} \mathrm{S} / \mathrm{A}\right)$ and the wt complemented strain N6 $\Delta h t r A / h t r A_{\mathrm{N} 6}(\Delta h t r A / h t r A)$ as control (Additional file 1: Figure S1). We observed no visible growth defect for $\Delta h t r A$ and $\Delta h t r A / h t r A$ S/A when they were grown under standard conditions $\left(37^{\circ} \mathrm{C}, \mathrm{GC}\right.$ agar medium) (Fig. 3a and Additional file 1: Figure S2A). As we have determined in recent studies, at $39^{\circ} \mathrm{C}, \Delta h t r A$ grew slower and at $41^{\circ} \mathrm{C}$ we observed a significant decrease in survival compared to the control strains [27]. To the contrary, $\Delta h t r A / h t r A$ S/A grew similarly to N6 wt and wt complemented strain $\Delta h t r A / h t r A$. Therefore, we assumed that proteolytically inactive HtrAS221A can suppress the temperature sensitive phenotype of the $\Delta$ tr $A$ strain (Fig. 3 and Additional file 1: Figure S2A).

As next we tested the effects of $\mathrm{pH}$ stress. The $\mathrm{pH}$ of the standard GC agar medium for $H$. pylori growth is 7.1. The change in pH to 5.2 or 7.7 caused a significant decrease in the survival of $\Delta h t r A$, especially at elevated temperature $\left(39^{\circ} \mathrm{C}\right)$. Again, the presence of HtrAS221A enabled growth of bacteria under the majority of chosen experimental conditions. The only exception was a combination of pH 5.2 and $39^{\circ} \mathrm{C}$ which was lethal for both, $\Delta h t r A$ and $\Delta h t r A / h t r A$ S/A (Fig. 4a and Additional file 1: Figure S2B).

In the following set of experiments we tested osmotic stress using ionic and nonionic stressors. We have noted that sucrose $(175 \mathrm{mOsm})$, which is non-ionic osmoticum, did not affect the viability of any of the tested strains (Fig. 4b and Additional file 1: Figure S2C). However, the stress caused by the increased concentration of salts, e.g. $\mathrm{NaCl}$ or $\mathrm{MgCl}_{2}$, had a significant impact on H. pylori growth. Visible colonies were smaller compared to controls, and $\Delta h \operatorname{tr} A$ grew very poorly at $37^{\circ} \mathrm{C}$, while at $39^{\circ} \mathrm{C}$ no colonies were formed (Fig. $4 \mathrm{~b}$ and Additional file 1: Figure S2C). Also, under these conditions expression of HtrAS221A was beneficial for $H$. pylori. Although the salt stress sensitivity of $\triangle$ htrA was not fully suppressed by HtrAS221A in the presence of $\mathrm{NaCl}$ at elevated temperature $\left(39^{\circ} \mathrm{C}\right)$, growth of bacteria was weaker. Thus, we can assume that the chaperone activity of HtrAS221A plays important protective role under osmotic stress 

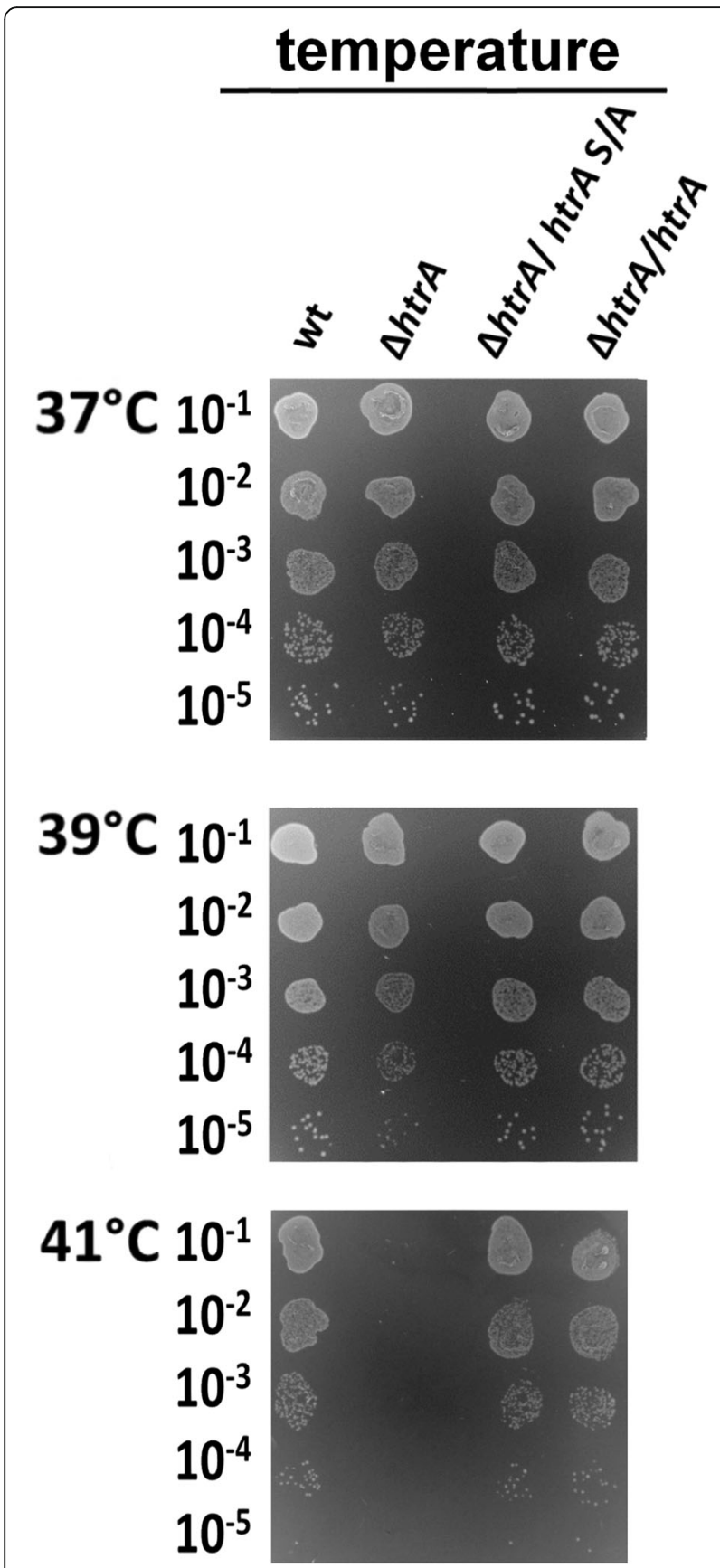

Fig. 3 Effects of temperature on the growth of H. pylori. Tested strains were: $\mathrm{N} 6 \mathrm{wt}, \triangle h t r A$, complemented strains with wt htrA ( $\triangle h t r A / h t r A)$ and with proteolytically inactive variant of $h t r A$ ( $\triangle h t r A$ ) htrAS/A). Serial dilutions of bacterial cultures were spotted onto GC agar plates and bacterial growth at three temperatures was assessed after 6 days of incubation on GC agar plates. The experiments were performed in triplicates and representative examples are shown

conditions (Fig. 4b). We have reported that the lack of $\mathrm{Htr}$ A did not influence survival of $\mathrm{H}$. pylori under oxidative stress induced by $\mathrm{H}_{2} \mathrm{O}_{2}$ or cumene hydroperoxide [27]. Accordingly, a lack of the proteolytic activity of $\mathrm{HtrA}_{H p}$ did not affect growth of bacteria in the presence of the oxidants
(Additional file 1: Figure S3). However, bacterial survival in the presence metronidazole was supported by the presence of $\mathrm{HtrA}_{H p}$ and $\mathrm{HtrAS} 221 \mathrm{~A}_{H p}$, while the metronidazoletreated $\triangle$ htrA cells grew poorly at $39^{\circ} \mathrm{C}$ (Fig. $5 \mathrm{~b}$ and Additional file 1: Figure S2D). Metronidazole is commonly used in a therapy against $H$. pylori [57], which is a redoxactive prodrug that needs to be activated by reduction of the nitro group attached to the imidazole ring. This reduction step leads to the production of DNA-damaging compounds, which can kill the bacterium [58]. A further action mechanism of metronidazole may lead to production of nitroradical anions that reduce $\mathrm{O}_{2}$ and thereby generate reactive oxygen species $[59,60]$. Therefore, the contribution of HtrA to protection against oxidative stress is possible.

Finally, we tested the effects of puromycin treatment. This antibiotic compound leads to the premature release of unfinished protein chains from ribosomes [61] and it causes the accumulation of improperly folded proteins [62]. Exposure of $H$. pylori to puromycin retarded the growth of all tested strains at $37^{\circ} \mathrm{C}$. At $39^{\circ} \mathrm{C}, \Delta h t r A$ did not form colonies in contrast to $\Delta h \operatorname{tr} A / h t r A$ S/A; hence, expression of HtrAS221A can suppress the negative effects of puromycin (Fig. 3c and Additional file 1: Figure S2E).

Lack of $h$ trA does not affect the level of secreted proteins Determination of the physiological function of the $\mathrm{HtrA}_{H p}$ protein in the bacterial cell has so far been significantly hampered due to the lack of a mutant lacking the functional $h t r A_{H p}$ gene. Previous attempts to inactivate the $h t r A_{H p}$ gene were unsuccessful, despite the usage of more than $100 \mathrm{H}$. pylori strains of various origin [63]. Now we obtained a $\Delta h t r A$ mutant in strain N6, and previously published analyses showed that in selected $H$. pylori strains (N6, 26695, J99, HPAG1, Shi470 and India7) no additional protease was found that could replace $\mathrm{HtrA}$ in function [28]. Using the htrA mutant strains we undertook an investigation how the lack of HtrA protein or its proteolytic activity in the bacterial cell may affect the level of cellular and secreted proteins. In this experiment, we inspected well-known secreted proteins of $H$. pylori such as, HtrA, UreB, NapA, GGT and GroEL, while intracellular HP1021, ClpB, DnaJ, Lon and CagA proteins served as negative controls. We found that the cellular content of the tested proteins was similar in all tested strains. Western blotting confirmed the lack of the HtrA protein in the corresponding mutant strain. In the case of CagA, HP1021, ClpB, DnaJ and Lon proteins, it was visible that they are not secreted outside the cell as expected. This result also confirmed that there were no broken cells or cell debris in the supernatant. Interestingly, the $\Delta h t r A / h t r A \mathrm{~S} / \mathrm{A}$ mutant secreted significant less HtrA protein compared to wt and complemented $\triangle$ htrA/htrA (Fig. 6). Analysis of the level of secreted UreB, NapA, GGT and GroEL 


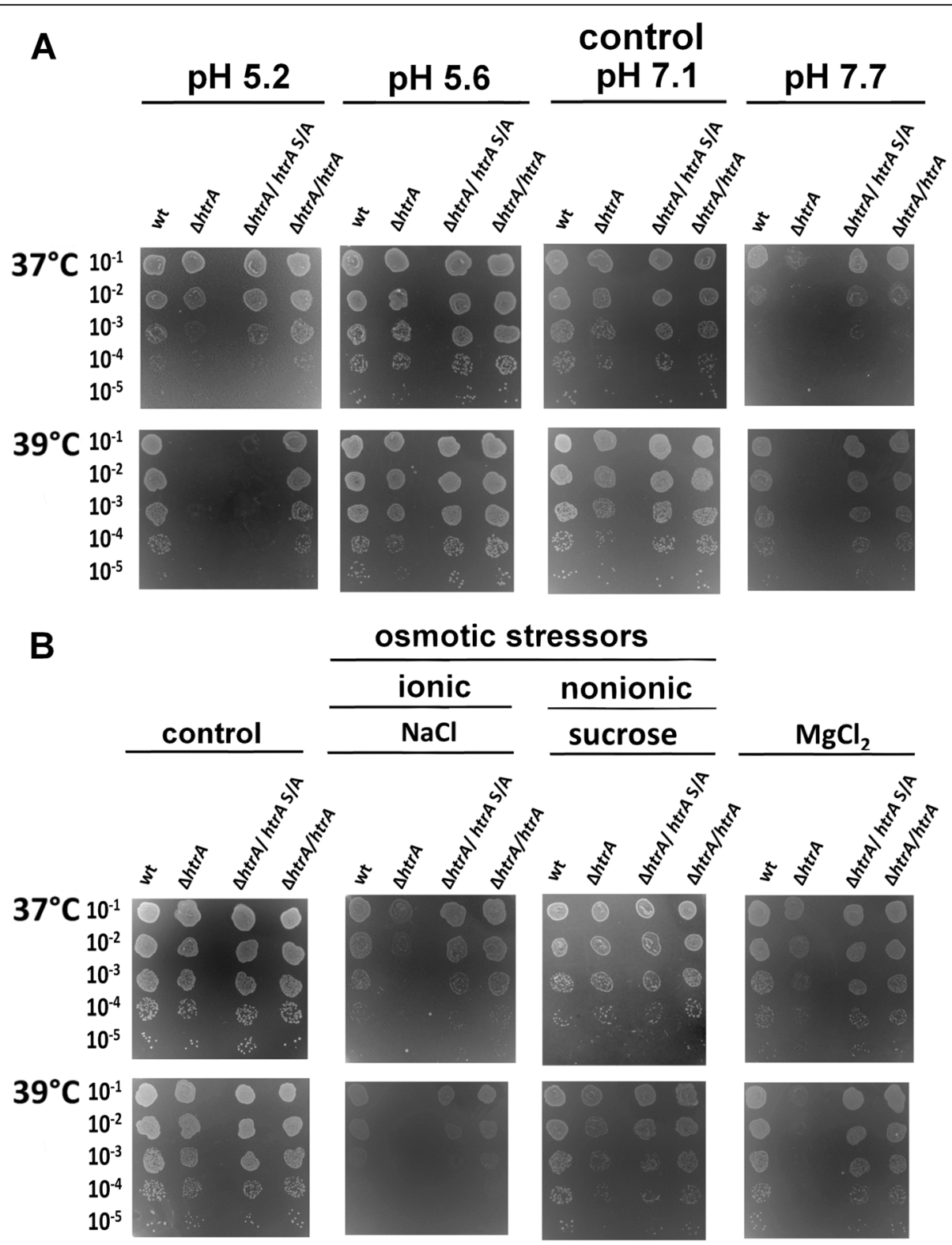

Fig. 4 Effects of $\mathrm{pH}$ (a) and osmotic stress (b) on the growth of H. pylori. We tested the following strains: N6 wt, $\triangle$ htrA, complemented strains with wt $h$ trA $(\triangle h \operatorname{trA} / \mathrm{htr} A)$ and with proteolytically inactive variant of $h$ trA ( $\triangle$ htrA/htrAS/A). For osmotic stress, bacteria were grown on GC agar plates for 6 days in the presence of sucrose $(175 \mathrm{mM}), \mathrm{NaCl}(85 \mathrm{mM})$ or $\mathrm{MgCl}_{2}(32 \mathrm{mM})$ at 37 or $39^{\circ} \mathrm{C}$. The experiments were performed in triplicates and representative examples are shown

proteins, however, indicated no significant differences in the level of these proteins between the tested strains (Fig. 6 and Additional file 1: Figure S4).

Expression of HtrA by H. pylori is important for disruption of E-cadherin in the adherens junctions of polarized MKN28 cells

In the next experiments we aimed to study the effect of lack of $h$ trA during infection in comparison with several wt $H$. pylori strains. For this purpose, confluent polarized MKN-28 epithelial cell monolayers were infected for $6 \mathrm{~h}$ with wt strains N6, 26695, J99, G27 and 7.13 as well as $\Delta h t r A, \Delta h t r A / h t r A S / A$ and complemented strain $\Delta h \operatorname{tr} A / h \operatorname{tr} A$. Infected and mock control cells were fixed and stained for immunofluorescence visualization using antibodies against the E- cadherin (green) and H. pylori (red). The uninfected mock control cells showed the typical E-cadherin signals between the neighboring cells in the monolayer as expected (Fig. 7a). When cells were infected by wt strains or by complemented strains, we observed disruption of E-cadherin in many areas of the cell culture (Fig. 7a, b, e-i, yellow arrows). The E-cadherin 


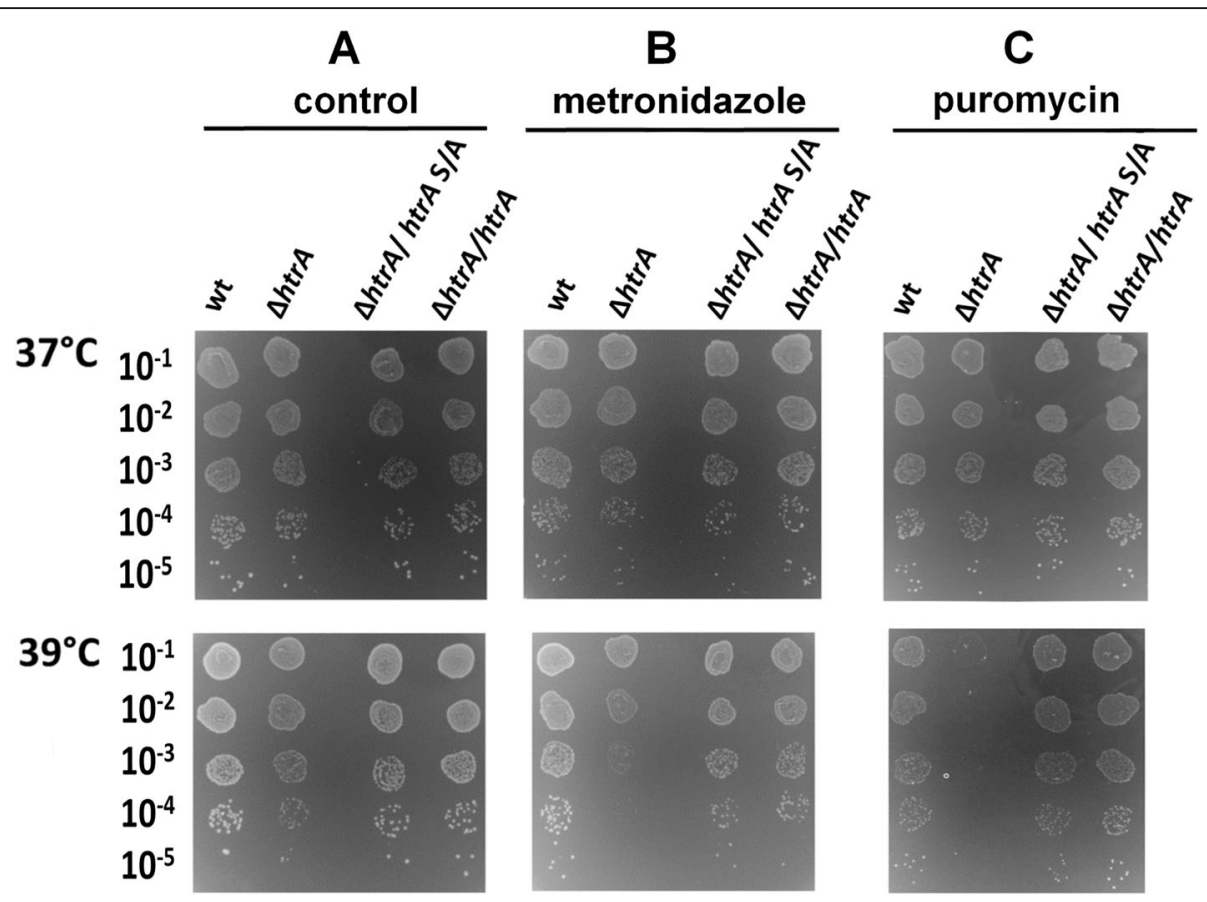

Fig. 5 Effects of metronidazole (b) and puromycin (c) on the growth of H. pylori. The following strains were tested: N6 wt, $\triangle h t r A$, complemented strains with wt $h$ trA $(\triangle h t r A / h t r A)$ and with proteolytically inactive variant of $h$ trA ( $\triangle$ htrA/htrAS/A). Serial dilutions of bacterial cultures were spotted onto GC agar plates without (a) and with (b) metronidazole or (c) puromycin and bacteria growth for 6 days. The experiments were performed in triplicate and the representative examples are shown

signals for some cells were downregulated (blue arrows) and were characterized by mislocalization of the protein. In contrast, infection with the $\Delta h \operatorname{tr} A$ and $\Delta h t r A / h t r A \mathrm{~S} / \mathrm{A}$ mutant strains resulted in no or only very low levels of disruption and mislocalization of E-cadherin (Fig. 7c, d). Interestingly, we noticed that level of disruption of intercellular junctions differs between strains. Therefore, we compared amounts of HtrA secreted by the examined $H$. pylori strains. For this purpose, we prepared liquid $H$. pylori cultures in $\mathrm{BB}$ medium containing $0.2 \% \beta$-cyclodextrin and cholesterol. Indeed, we observed significant differences in the secretion of the HtrA protein between the tested strains (Fig. 8b and Fig. 9a). For 26695 and G27, the levels of secreted HtrA were the highest and it was even 6-7 times greater compared to N6, J99 and 7.13, which secreted less HtrA. Strain $J 99$ also secreted very low amounts of UreB and GroEL proteins. Only strains 26695 and G27 showed differences in HtrA level in relation to other secretory proteins. Probably these strains are characterized by the increased secretion of numerous of secreted proteins, not only HtrA. To verify proteolytic activity of secreted HtrAs, we incubated equal amounts of $H$. pylori supernatant protein with $\beta$-casein, a universal substrate for proteases. We found that the level of digested $\beta$-casein correlated with the amount of HtrA secreted by the tested H. pylori strains (Fig. 9). In the case of strains 26695 and G27, the majority of the full-length $\beta$-casein protein was digested, and for N6, 599 and 7.13 we obtained about 20$30 \%$ digested substrate. In the $\Delta h t r A$ mutant, we observed a slight digestion of $\beta$-casein, suggesting that other active protease(s) is/are present in the supernatants (Fig. 9b and c). To have additional information about the proteolytic activity of secreted $\mathrm{HtrA}_{H p}$, we further tested N6 wt, $\Delta h t r A, \Delta h t r A / h t r A$ S/A and the complemented $\Delta h t r A / h t r A$ strain using casein zymography. For this purpose, we used samples from liquid culture, pellets and supernatants after concentration. As expected, for $\Delta h t r A$ and $\Delta h t r A / h t r A$ S/A, we observed that they are unable to digest casein in contrast to N6 wt and $\Delta$ trA/htrA, which form visible HtrA trimers (Fig. 10).

\section{Discussion}

For many pathogenic bacteria, HtrA has been characterized as an important virulence factor $[64,65]$. In the present study, we focused on characterizing the chaperone activity of $\mathrm{HtrA}_{H p}$ in vivo and in vitro that has not yet been investigated. We studied the in vitro chaperone activity in $H$. pylori using two methods, which allowed us to observe the resulting lysozyme aggregates after the use of a reducing factor in the presence or absence of HtrA. We were able to show that $\mathrm{HtrA}_{H p}$ efficiently inhibits the lysozyme aggregation process similar to the $\mathrm{Htr}_{E c}\left(\operatorname{DegP} \mathrm{P}_{E c}\right)$ protein, whose chaperone activity has already been described in our previous reports [20, 42]. Moreover, this 


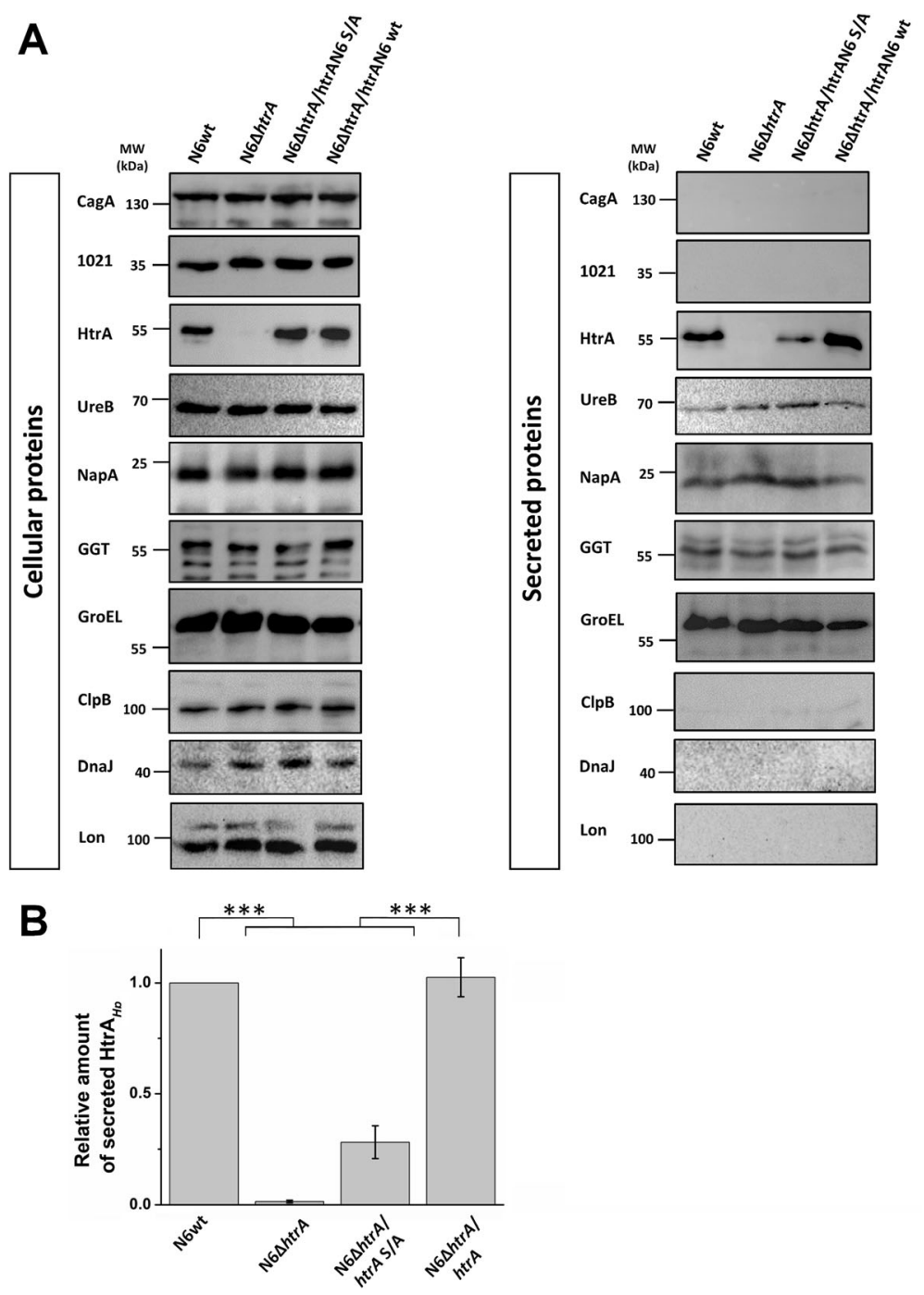

Fig. 6 Mutation of $\mathrm{HtrA}_{H p}$ has no effect on the secretion of proteins. Proteolytic activity of the HtrA $\mathrm{Hp}_{p}$ protein is important in the process of secretion of this protein outside the bacterial cell. Total proteins were labelled as a pellet, bacteria-free secreted samples was labelled as a supernatant. a Western blotting analysis of $\mathrm{H}$. pylori lysates. The CagA protein was used as a control (as a non-secreted protein). b The band intensities of secreted proteins were quantified densitometrically using 1Dscan Ex program and the relative amount of secreted protein is given. Significant differences were analyzed using Bonferroni test $\left.{ }^{* * *} p<0.001\right)$. The standard error of mean (SEM) was calculated using at least three repetitions. Immunodetection using Lon antibodies was performed in duplicate

activity is effective under different conditions of $\mathrm{pH}$ and temperature stresses.

Using recombinant proteins, the chaperone activity was previously described for the HtrAs of Campylobacter jejuni [34], Stenotrophomonas maltophilia [42], Haemophilus parasuis [66] and Chlamydia trachomatis [67], which is similar to our present findings for $\mathrm{HtrA}_{H p}$ and $H \operatorname{tr} \mathrm{A}_{E c}$ $\left(\operatorname{DegP}_{E c}\right)$. Interestingly, the chaperone activity was also detected in the human orthologs (HTRA 1-3 [68-71] and suggested for HTRA4 [72]) and a yeast HtrA protein [73]. Thus, conservation of HtrA chaperone activity in the evolution of multiple species may indicate their overall importance, however, this activity is still not fully understood.
Together with our previous publication [27], we described here the role of HtrA (both chaperone and proteolytic activities) in $H$. pylori under stress conditions. For these tests, we used N6 wt and its mutants N6 $\Delta h t r A$ $(\Delta h t r A)$ and N6 $\Delta h t r A / h t r A_{\mathrm{N} 6}$ S221A $(\Delta h t r A / h t r A$ S/A) as well as its complemented strain $\Delta h \operatorname{tr} A / h \operatorname{tr} A_{\mathrm{N} \sigma}(\Delta h \operatorname{tr} A / h \operatorname{tr} A)$, for which construction methods have been presented in previous publications $[27,28]$. The strains have been exposed to thermal, osmotic and $\mathrm{pH}$ stressors as well as to the antibiotics puromycin and metronidazole. All of these stresses can affect the proper functioning of a bacterial cell. Puromycin causes the premature termination of protein synthesis in the translation process, which results in a large 

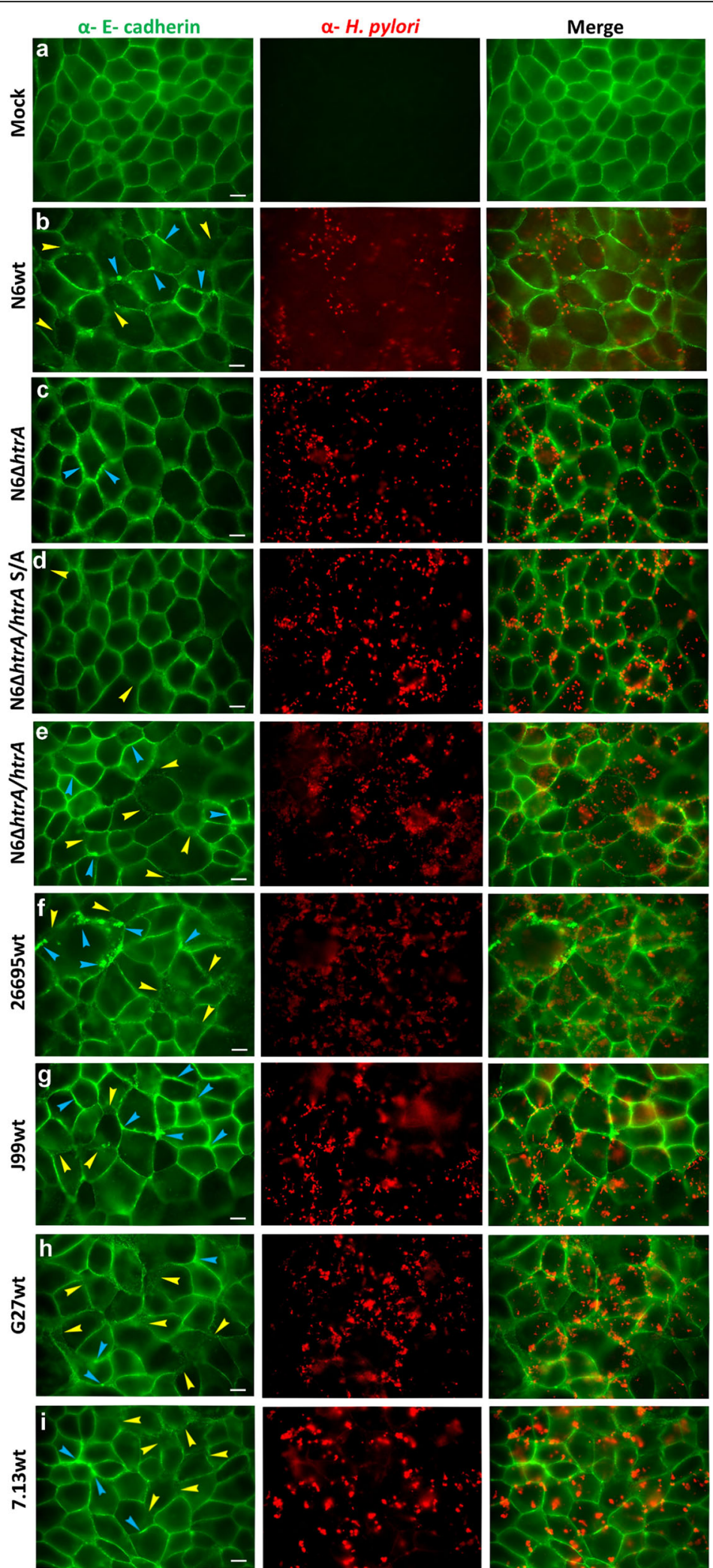

Fig. 7 (See legend on next page.) 
(See figure on previous page.)

Fig. 7 Importance of HtrA on disruption of E- cadherin based cell-to-cell junctions during infection with H. pylori. Polarized MKN-28 cells were left

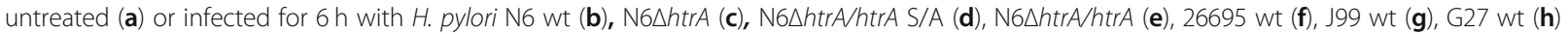
and 7.13 wt (i). The cells were subjected to immunofluorescence staining detected E-cadherin (green) and H. pylori (red). Arrowheads mark cells showing significantly downregulated (blue) or disrupted (yellow) E-cadherin signals. The scale bar corresponds to $10 \mu \mathrm{m}$
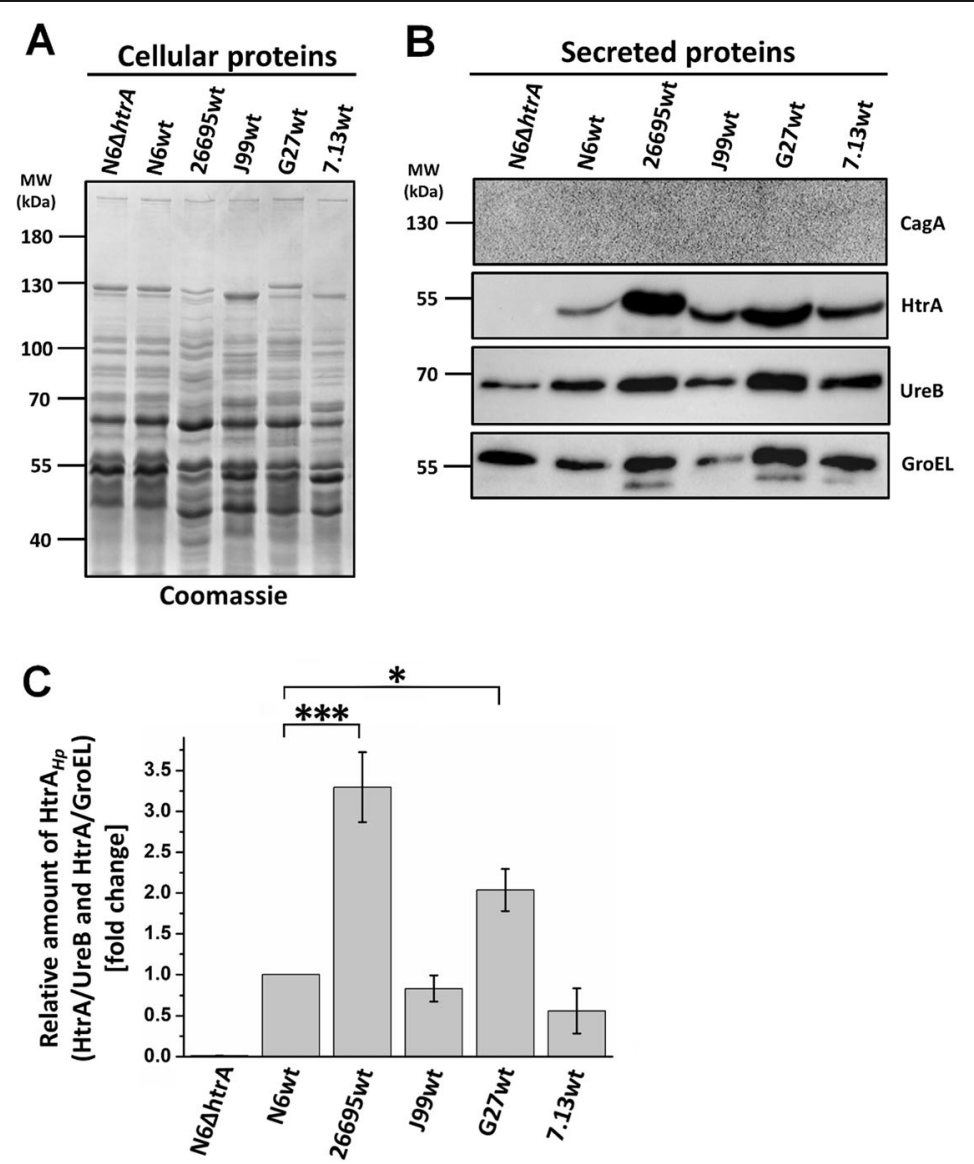

D

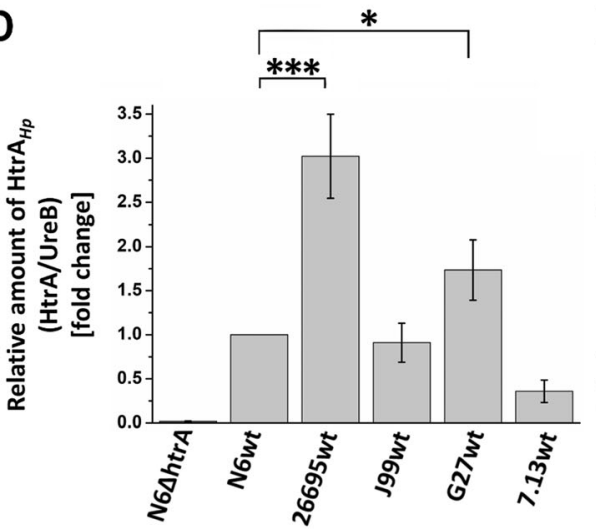

$\mathbf{E}$

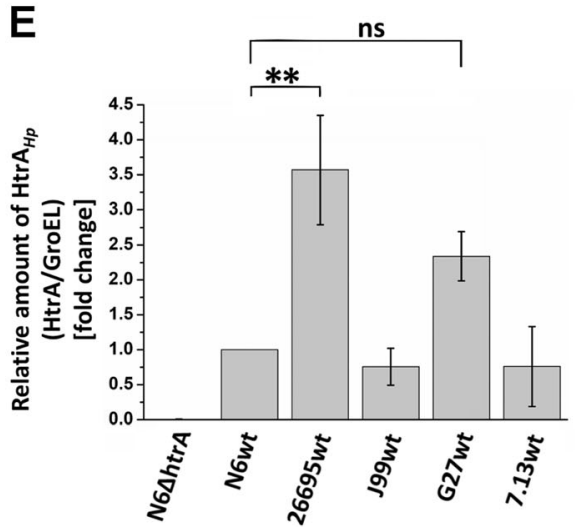

Fig. 8 Differences in HtrA secretion by several H. pylori strains. a Total cellular protein profiling of the H. pylori lysates by Coomassie-stained SDSPAGE. $\mathbf{b}$ Western blot analysis of level secreted proteins HtrA, UreB and GroEL. CagA was used as a control. c-e The amount of HtrA relative to other secreted proteins (UreB and GroEL). Significant differences were analyzed using Bonferroni test $\left(p<0.05^{*}, p<0.01{ }^{* *}\right.$ and $\left.p<0.001{ }^{* *}\right)$. The standard error of mean (SEM) was calculated using at least three repetitions. ns means no significant differences 


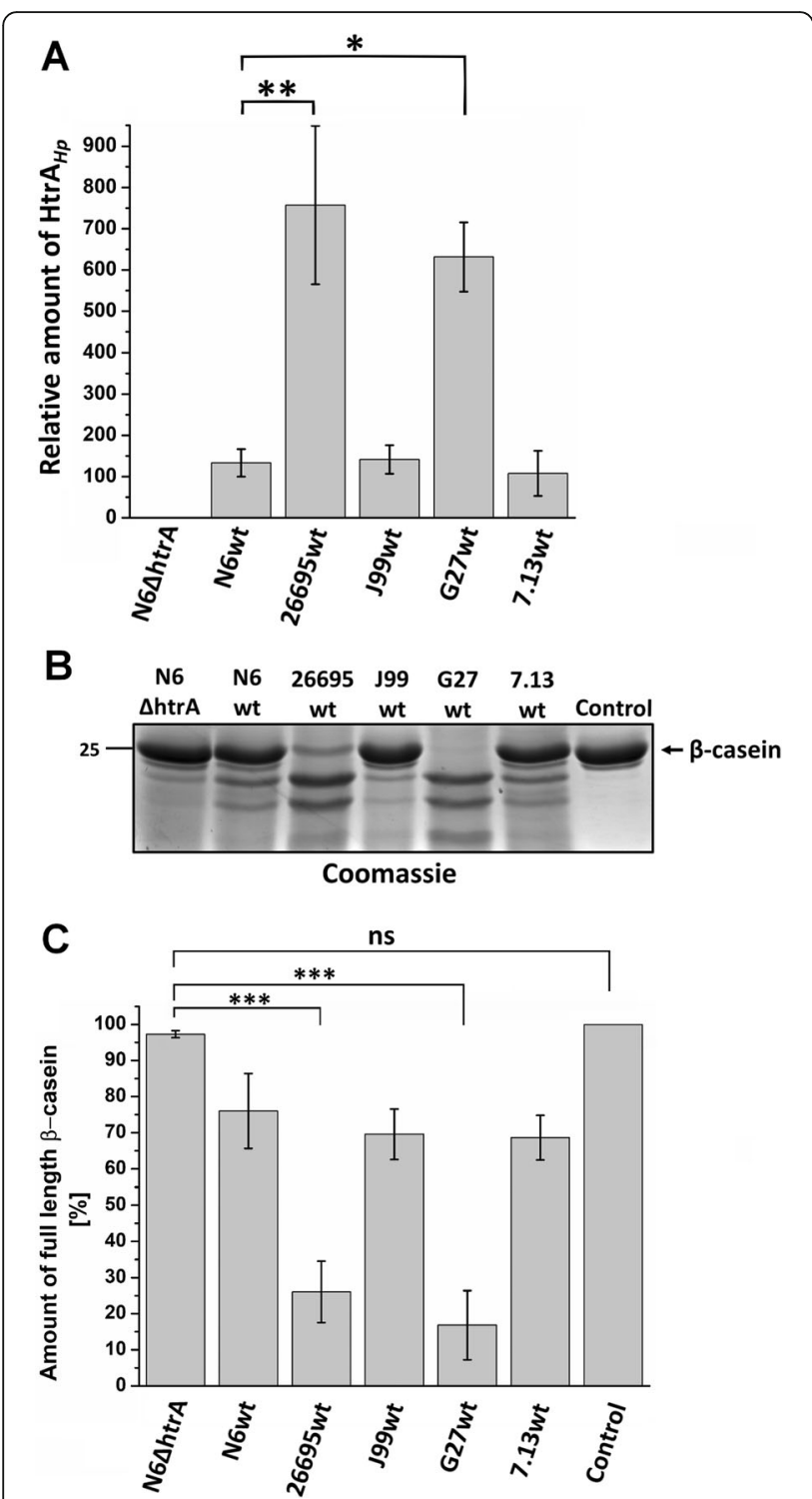

Fig. 9 Differences in proteolytic activity of secreted HtrA by several H. pylori strains. a Relative amount of secreted $\mathrm{HtrA}_{H p}$ was measured by Western blotting using densitometric method. $\mathbf{b}$ Digestion of $\beta$ casein using supernatants from overnight grown $H$. pylori strains. The Coomassie-stained gel showed the result after $16 \mathrm{~h}$ incubation of reaction mixture. $\mathbf{c}$ The band intensities of $\beta$-casein were quantified densitometrically and sample without supernatant was set as a $100 \%$. Significant differences were analyzed using Bonferroni test $\left(p<0.05^{*}, p<0.01{ }^{* *}\right.$ and $\left.p<0.001{ }^{* *}\right)$. The standard error of mean (SEM) was calculated using at least three repetitions. ns means no significant differences

amount of misfolded proteins that can form toxic aggregates for cells $[61,62]$. Metronidazole induces the production of DNA damaging radicals [74] and probably other reactive species that denature other cellular macromolecules are also formed [59,60]. Other tested stresses such as osmotic, temperature, acid, basic and oxidative factors can result in protein denaturation and aggregation, which can lead to cell death. Under such circumstances, HtrA acts as an element of the cellular protein quality control system and can prevent the formation of protein aggregates through their degradation (proteolytic activity) or by keeping them in a soluble state (chaperone activity). In our previous publication, we reported that the htrA deletion mutant in $H$. pylori is more sensitive to the majority of stress tested in comparison to the wt strain [27]. Now we demonstrated that the strain lacking proteolytic activity of HtrA showed a high degree of resistance to the stresses studied and the mutant grew similarly compared to the N6 wt strain under the majority of tested experimental conditions. These results allowed us to propose that the HtrA chaperone activity is sufficient for $H$. pylori to withstand a variety of adverse environmental conditions. By comparison, the chaperone activity of $C$. jejuni HtrA also plays important roles in protection of the bacteria against heat or oxidative stress. However, when the bacteria were exposed to both stresses, the strain lacking proteolytic activity did not survive [34].

In several bacterial species, HtrA homologs are involved in protein secretion [75]. To examine a potential role of HtrA for protein secretion by the H. pylori cell, we analyzed the presence of typical secreted proteins in the culture supernatant. We investigated the expression and secretion levels of UreB, NapA, GGT, and HtrA proteins. The urease is an important survival and virulence factor, which is produced in large amounts by $H$. pylori. This protein allows the bacteria to colonize and induce inflammatory responses in the gastric epithelium. The enzymatic activity of urease causes hydrolysis of urea into ammonia, which consequently leads to neutralizing the acid environment around the bacteria [76] and urease plays a role in inflammasome activation [77] and induction of hypoxia-induced factor, HIFa [78]. Neutrophil-activating protein (NapA) is important in inducing neutrophil recruitment through the endothelium and can stimulate host cell production of reactive oxygen species $[8,79]$. Tests have shown that NapA plays a role in preventing oxidative DNA damage and is crucial for H. pylori colonization [8]. On the other hand, GGT is a bacterial virulence factor, which causes glutamine and glutathione consumption as well as the production of ammonia and reactive oxygen species in the host. Moreover, GGT can induce apoptosis and necrosis in gastric epithelial cells [80]. Interestingly, we did not observe differences in the expression and secretion levels of UreB, NapA and GGT in the $\Delta h t r A$ and $\Delta h t r A / h t r A$ S/A strains, and also did not observe changes in the survival of the examined strains (Additional file 1: Figure S2). In the case of $\mathrm{HtrA}_{H p}$, we saw the lower amount of secreted HtrA in the $\Delta h t r A / h t r A$ S/A strain suggesting that the proteolytic activity of $\mathrm{HtrA}_{H p}$ is required for efficient secretion into the extracellular environment. This finding is in contrast to previous observations made with 


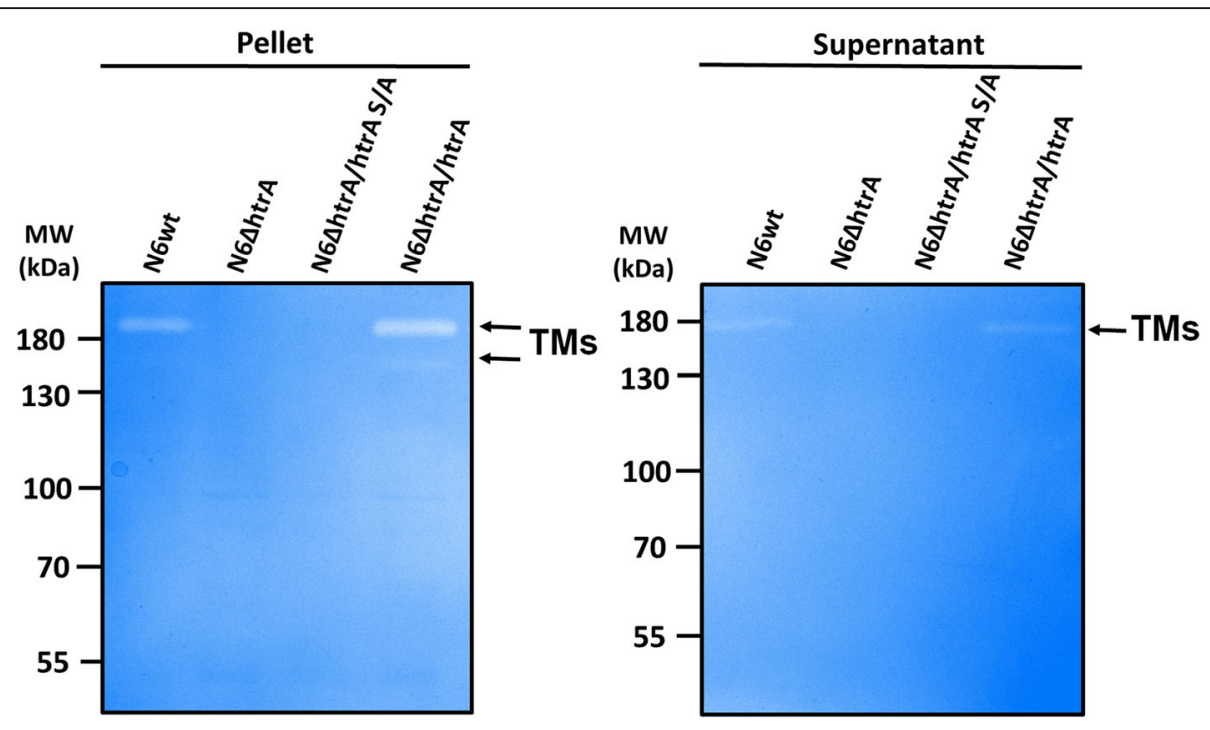

Fig. 10 Analysis of HtrA proteolytic activity in H. pylori N6 wt and mutant strains. The proteolytic activity of HtrA was analysed by casein zymography. Supernatants and pellets from liquid culture were tested. The position of proteolytically active HtrA trimers (TMs) on the gels is indicated with arrows

C. jejuni $\mathrm{HtrA}$, in which the protease activity played no role for $\mathrm{HtrA}_{C j}$ secretion [33]. The reason for these differences are yet unknown and should be studied in future experiments.

We also checked the expression and secretion levels of several chaperone proteins such as GroEL, ClpB, DnaJ in the various genetic htrA backgrounds of $H$. pylori. The presence of genes encoding these proteins in $H$. pylori has been demonstrated in earlier reports $[9,81,82]$, but are not characterized at much detail. However, it is known that in H. pylori the levels of GroEL increase during heat shock [83] and $\mathrm{GroEL}_{H p}$ plays a role in regulating the activity of urease enzyme [84]. In addition, $H$. pylori without $\operatorname{clp} B$ are more sensitive to temperature stress [81]. The co-chaperone DnaJ was shown to stimulate ATPase activity of DnaK, enhancing the recognition and binding of DnaK substrates [82]. In our present studies, we did not observe changes in the expression level of chaperones under physiological conditions in vitro. Perhaps, this could change under any stressful conditions. Among the H. pylori chaperones, only GroEL is known to be secreted into the extracellular environment. In the case of C. jejuni, htrA deletion resulted in the overproduction of DnaK and $\mathrm{ClpB}$, while in the corresponding protease-deficient S/A mutant only the overproduction of ClpB was observed in vitro [34]. Interestingly, at elevated temperatures, the overproduction of DnaK and $\mathrm{ClpB}$ proteins was clearly visible for both strains [34].

As negative control, we checked the level of CagA, which is probably the best studied $H$. pylori virulence factor. Moreover, translocated CagA can dysregulate signal transduction of gastric epithelial cells, which is involved in chronic inflammation and malignancy by changing cell polarity, apoptosis, and proliferation [63]. It is known, that CagA is an effector protein translocated into host cells and not secreted into the supernatant, so we used it as a control for this experiment, and we observed the lack of CagA in our supernatant samples.

In addition, we have not seen an effect of the lack of $h$ trA on the expression of the HP1021 protein that is encoded next to $h t r A$ and involved in the chromosomal replication process [51] and on the Lon protease, which is associated with specific recognition and degradation of incomplete, damaged, and non-native proteins [85].

To learn more about the role of HtrA in the virulence process of $\mathrm{H}$. pylori, we checked the impact of HtrA deficiency and its proteolytic activity during one of the most important stages of infection, it means the disruption of E-cadherin-based junctions between neighboring epithelial cells. As a model system, we infected polarized MKN-28 cells with the above discussed strains followed by immunofluorescence of E-cadherin. Non-infected control cells showed the proper cell-to-cell junctions with E-cadherin staining. Cells infected by N6 wt, N6 complemented $\Delta$ trA/htrA or other wt strains (26695, J99, G27 and 7.13) showed the significant disruption of junctions between cells, as indicated by the dispersed Ecadherin signals and changes in the shape of MKN-28 cells (Fig. 7). In contrast, during infection with $\Delta h t r A$ and $\Delta h \operatorname{trA} / h \operatorname{tr} A$ S/A mutant strains the epithelial cell structure remained widely preserved, and only very low levels of disruption and mislocalization of E-cadherin were observed (Fig. 7a, b, e). These observations are in 
line with previous results that $\mathrm{Htr}_{H p}$ is able to digest the extracellular part of E-cadherin $[25,86,87]$ and that overproduction of two htrA gene copies in $H$. pylori caused a more pronounced breakdown of E-cadherin compared to the 26695 wt strain in infected Caco- 2 cells [47]. As we observed certain strain-dependent differences in the efficiency of infection, we decided to check the levels of HtrA secreted by various $H$. pylori strains. Strains 26695 and G27 exported higher levels of HtrA, compared to N6, J99 and 7.13 (Fig. 9a). Casein digestion by extracellular $H$. pylori proteins has shown that proteolytic activity correlated with the amounts of HtrA secreted by the strains (Fig. 9b and c). These strains also showed significant differences in HtrA secretion compared to other secreted proteins, especially in the case of UreB (Fig. 8c-e). In addition, casein digestion was verified using zymography. For the supernatant samples it was more difficult to demonstrate proteolytic activity due to the small amounts of secreted HtrA by strain N6, as confirmed above (Fig. 10).

\section{Conclusions}

Proteases of the HtrA family exhibit both proteolytic and chaperone activities. In this work, we have expanded the previously published results, now focusing on the chaperone activity of the $\mathrm{HtrA}_{H p}$ protein, which has not been characterized before. Analyses of the recombinant protein have shown that $\mathrm{HtrA}_{H p}$ possesses chaperone activity that inhibits the aggregation of lysozyme and is stable under various $\mathrm{pH}$ and temperature conditions. Using a previously constructed $\Delta h t r A$ deletion knockout and protease-deficient HtrA point mutant in strain N6 $[27,28]$, we have now demonstrated the importance of chaperone activity under thermal, $\mathrm{pH}$ and osmotic stress conditions. Moreover, we have proven that the lack of htrA in H. pylori does not affect the expression levels of many other proteins (both cellular and secreted). In addition, we could demonstrate that $H$. pylori lacking the proteolytic activity of HtrA exhibit reduced the levels of secreted HtrA. We also compared the secretion levels of HtrA from different $H$. pylori strains and showed significant differences in the amount of secreted HtrA, correlating with different efficiencies in the digestion of the substrate $\beta$-casein. Moreover, we have demonstrated the significant effect of HtrA on E-cadherin during infection of human polarized epithelial cells.

\section{Supplementary information}

Supplementary information accompanies this paper at https://doi.org/10. 1186/s12964-019-0481-9.

Additional file 1: Figure S1. Schemes of the htrA locus in H. pylori and the flanking chromosomal regions. Figure S2. Survival of the stressexposed $H$. pylori cells. Figure S3. Effects of oxidative stress on the growth of various $\mathrm{H}$. pylori strains. Figure S4. Mutation of htrA has no effect on the secretion of various proteins by $H$. pylori.

\section{Abbreviations}

CagA: Cytotoxicity-associated immunodominant antigen; Cj: Campylobacter jejuni; ClpB: Chaperone protein ClpB; DnaJ: Chaperone protein DnaJ; DnaK: chaperone protein DnaK; FITC: fluorescein isothiocyanate; GGT: Gamma-glutamyltransferase; GroEL: 60 kDa chaperonin/ Heat shock protein 60; Hp: Helicobacter pylori; HtrA: High- Temperature Requirement A; Ibp: small heat shock protein; Lon: Lon protease; NapA: Neutrophil-activating protein NapA; UreB: Urease subunit beta; VacA: Vacuolating cytotoxin autotransporter

\section{Acknowledgements}

We are grateful to Dr. Sabina Kędzierska- Mieszkowska from Department of General and Medical Biochemistry (University of Gdansk) for the ClpB antibodies and Prof. Barbara Lipińska for the GroEL antibodies.

\section{Authors' contributions}

Performed the experiments; designed and assembled all figures and table: UZ. Conceived and designed the experiments: UZ, AH, JS-G, SB. Analyzed the data: UZ, AH, AZ-P, JS-G, SB.

Contributed reagents/materials/analysis tools: JS-G, SB. Supervised the study: JS-G, SB. Wrote the paper: UZ, JS-G, SB. All authors read and approved the final manuscript.

Authors' information

Not applicable.

Funding

UZ and JSG were supported by the National Science Centre grant UMO2016/21/B/NZ2/01775, and SB by DFG-grant A04 in CRC-1181.

Availability of data and materials

The datasets supporting the conclusions of this article are included within the article and its additional files.

Ethics approval and consent to participate

Not applicable.

Consent for publication

Not applicable.

Competing interests

The authors declare that they have no competing interests.

\section{Author details}

${ }^{1}$ Division of Microbiology, Department of Biology,

Friedrich-Alexander-University Erlangen-Nürnberg, Erlangen, Germany. ${ }^{2}$ Department of General and Medical Biochemistry, Faculty of Biology, University of Gdańsk, Gdańsk, Poland. ${ }^{3}$ Department of Microbiology, Hirszfeld Institute of Immunology and Experimental Therapy, Polish Academy of Sciences, Wroclaw, Poland.

Received: 6 August 2019 Accepted: 11 November 2019

Published online: 03 December 2019

\section{References}

1. Vakil N, Malfertheiner P, Chey WD. Helicobacter pylori infection. N Engl J Med. 2010:363:595; author reply 596. https://doi.org/10.1056/NEJMc1006158.

2. Dunn BE, Roop RM, Sung CC, Sharma SA, Perez-Perez Gl, Blaser MJ. Identification and purification of a cpn60 heat shock protein homolog from Helicobacter pylori. Infect Immun. 1992:60:1946-51.

3. Slonczewski JL, McGee DJ, Phillips J, Kirkpatrick C, Mobley HL. pHdependent protein profiles of Helicobacter pylori analyzed by twodimensional gels. Helicobacter. 2000;5:240-7.

4. Scott D, Weeks D, Melchers K, Sachs G. The life and death of Helicobacter pylori. Gut. 1998;43(Suppl 1):S56-60. https://doi.org/10.1136/gut.43.2008.s56. 
5. Cover TL, Blanke SR. Helicobacter pylori VacA, a paradigm for toxin multifunctionality. Nat Rev Microbiol. 2005;3:320-32. https:/doi.org/10.1038/ nrmicro1095.

6. Kim N, Weeks DL, Shin JM, Scott DR, Young MK, Sachs G. Proteins released by Helicobacter pylori in vitro. J Bacteriol. 2002;184:6155-62. https://doi.org/ 10.1128/jb.184.22.6155-6162.2002.

7. Valenzuela M, Bravo D, Canales J, Sanhueza C, Díaz N, Almarza O, et al. Helicobacter pylori-induced loss of survivin and gastric cell viability is attributable to secreted bacterial gamma-glutamyl transpeptidase activity. J Infect Dis. 2013:208:1131-41. https://doi.org/10.1093/infdis/jit286.

8. Wang G, Hong Y, Olczak A, Maier SE, Maier RJ. Dual roles of Helicobacter pylori NapA in inducing and combating oxidative stress. Infect Immun. 2006;74:6839-46. https://doi.org/10.1128/IAl.00991-06.

9. González-López MA. Velázquez-Guadarrama N, Romero-Espejel ME, Olivares-Trejo JdJ. Helicobacter pylori secretes the chaperonin GroEL (HSP60), which binds iron. FEBS Lett. 2013;587:1823-8. https://doi.org/10. 1016/j.febslet.2013.04.048.

10. Bumann D, Aksu S, Wendland M, Janek K, Zimny-Arndt U, Sabarth N, et al. Proteome analysis of secreted proteins of the gastric pathogen Helicobacter pylori. Infect Immun. 2002;70:3396-403. https://doi.org/10.1128/iai.70.7.33963403.2002.

11. Tomoyasu T, Mogk A, Langen H, Goloubinoff P, Bukau B. Genetic dissection of the roles of chaperones and proteases in protein folding and degradation in the Escherichia coli cytosol. Mol Microbiol. 2001;40:397-413.

12. Wickner S, Maurizi MR, Gottesman S. Posttranslational quality control: folding, refolding, and degrading proteins. Science. 1999;286:1888-93. https://doi.org/10.1126/science.286.5446.1888.

13. Matuszewska E, Kwiatkowska J, Ratajczak E, Kuczyńska-Wiśnik D, Laskowska $\mathrm{E}$. Role of Escherichia coli heat shock proteins $\mathrm{IbpA}$ and $\mathrm{lbpB}$ in protection of alcohol dehydrogenase AdhE against heat inactivation in the presence of oxygen. Acta Biochim Pol. 2009:56:55-61.

14. Weibezahn J, Schlieker C, Bukau B, Mogk A. Characterization of a trap mutant of the AAA+ chaperone ClpB. J Biol Chem. 2003;278:32608-17. https://doi.org/10.1074/jbc. M303653200.

15. Ghosh P. Process of protein transport by the type III secretion system. Microbiol Mol Biol Rev. 2004;68:771-95. https://doi.org/10.1128/MMBR.68.4. 771-795.2004.

16. Green ER, Mecsas J. Bacterial secretion systems: an overview. Microbiol Spectr. 2016. https://doi.org/10.1128/microbiolspec VMBF-0012-2015.

17. Lipinska B, Fayet O, Baird L, Georgopoulos C. Identification, characterization, and mapping of the Escherichia coli htrA gene, whose product is essential for bacterial growth only at elevated temperatures. J Bacteriol. 1989;171: 1574-84.

18. Spiess C, Beil A, Ehrmann M. A temperature-dependent switch from chaperone to protease in a widely conserved heat shock protein. Cell. 1999;97:339-47.

19. Wonderling LD, Wilkinson BJ, Bayles DO. The htrA (degP) gene of Listeria monocytogenes $10403 \mathrm{~S}$ is essential for optimal growth under stress conditions. Appl Environ Microbiol. 2004;70:1935-43. https://doi.org/10. 1128/aem.70.4.1935-1943.2004.

20. Skorko-Glonek J, Laskowska E, Sobiecka-Szkatula A, Lipinska B. Characterization of the chaperone-like activity of HtrA (DegP) protein from Escherichia coli under the conditions of heat shock. Arch Biochem Biophys. 2007:464:80-9. https://doi.org/10.1016/j.abb.2007.04.006.

21. Humphreys S, Stevenson A, Bacon A, Weinhardt AB, Roberts M. The alternative sigma factor, sigmaE, is critically important for the virulence of Salmonella typhimurium. Infect Immun. 1999;67:1560-8.

22. Wilson RL, Brown LL, Kirkwood-Watts D, Warren TK, Lund SA, King DS, et al. Listeria monocytogenes $10403 \mathrm{~S} \mathrm{HtrA}$ is necessary for resistance to cellular stress and virulence. Infect Immun. 2006;74:765-8. https://doi.org/10.1128/ |Al.74.1.765-768.2006.

23. Cortés G, de Astorza B, Benedí VJ, Albertí S. Role of the htrA gene in Klebsiella pneumoniae virulence. Infect Immun. 2002;70:4772-6.

24. Li SR, Dorrell N, Everest PH, Dougan G, Wren BW. Construction and characterization of a Yersinia enterocolitica O:8 high-temperature requirement (htrA) isogenic mutant. Infect Immun. 1996;64:2088-94

25. Hoy B, Löwer M, Weydig C, Carra G, Tegtmeyer N, Geppert T, et al. Helicobacter pylori HtrA is a new secreted virulence factor that cleaves Ecadherin to disrupt intercellular adhesion. EMBO Rep. 2010;11:798-804. https://doi.org/10.1038/embor.2010.114.

26. Tegtmeyer N, Wessler S, Necchi V, Rohde M, Harrer A, Rau TT, et al. Helicobacter pylori employs a unique basolateral type IV secretion mechanism for CagA delivery. Cell Host Microbe. 2017;22:552-560.e5. https://doi.org/10.1016/j.chom.2017.09.005.

27. Zarzecka U, Modrak-Wójcik A, Figaj D, Apanowicz M, Lesner A, Bzowska A, et al. Properties of the HtrA protease from bacterium Helicobacter pylori whose activity is indispensable for growth under stress conditions. Front Microbiol. 2019;10:961. https://doi.org/10.3389/fmicb.2019.00961.

28. Zawilak-Pawlik A, Zarzecka U, Żyła-Uklejewicz D, Lach J, Strapagiel D, Tegtmeyer $\mathrm{N}$, et al. Establishment of serine protease htrA mutants in Helicobacter pylori is associated with secA mutations. Sci Rep. 2019;9:11794. https://doi.org/10.1038/s41598-019-48030-6.

29. Hoy B, Brandstetter $H$, Wessler S. The stability and activity of recombinant Helicobacter pylori HtrA under stress conditions. J Basic Microbiol. 2013;53: 402-9. https://doi.org/10.1002/jobm.201200074.

30. Backert S, Bernegger S, Skórko-Glonek J, Wessler S. Extracellular HtrA serine proteases: an emerging new strategy in bacterial pathogenesis. Cell Microbiol. 2018;20:e12845. https://doi.org/10.1111/cmi.12845.

31. Baud C, Gutsche I, Willery E, de Paepe D, Drobecq H, Gilleron M, et al. Membrane-associated DegP in Bordetella chaperones a repeat-rich secretory protein. Mol Microbiol. 2011;80:1625-36. https://doi.org/10.1111/j. 1365-2958.2011.07672.x.

32. Bæk KT, Vegge CS, Brøndsted L. HtrA chaperone activity contributes to host cell binding in Campylobacter jejuni. Gut Pathog. 2011;3:13. https://doi.org/ 10.1186/1757-4749-3-13

33. Boehm M, Lind J, Backert S, Tegtmeyer N. Campylobacter jejuni serine protease HtrA plays an important role in heat tolerance, oxygen resistance, host cell adhesion, invasion, and transmigration. Eur J Microbiol Immunol (Bp). 2015;5(1):68-80.

34. Baek KT, Vegge CS, Skórko-Glonek J, Brøndsted L. Different contributions of HtrA protease and chaperone activities to Campylobacter jejuni stress tolerance and physiology. Appl Environ Microbiol. 2011;77:57-66. https:// doi.org/10.1128/AEM.01603-10.

35. Hanahan D. Studies on transformation of Escherichia coli with plasmids. J Mol Biol. 1983;166:557-80. https://doi.org/10.1016/S0022-2836(83)80284-8.

36. Tomb JF, White O, Kerlavage AR, Clayton RA, Sutton GG, Fleischmann RD, et al. The complete genome sequence of the gastric pathogen Helicobacter pylori. Nature. 1997;388:539-47. https://doi.org/10.1038/41483.

37. Alm RA, Ling LS, Moir DT, King BL, Brown ED, Doig PC, et al. Genomicsequence comparison of two unrelated isolates of the human gastric pathogen Helicobacter pylori. Nature. 1999;397:176-80. https://doi.org/10. 1038/16495.

38. Baltrus DA, Amieva MR, Covacci A, Lowe TM, Merrell DS, Ottemann KM, et al. The complete genome sequence of Helicobacter pylori strain G27. J Bacteriol. 2009;191:447-8. https://doi.org/10.1128/JB.01416-08.

39. Franco AT, Israel DA, Washington MK, Krishna U, Fox JG, Rogers AB, et al. Activation of beta-catenin by carcinogenic Helicobacter pylori. Proc Natl Acad Sci U S A. 2005;102:10646-51. https://doi.org/10.1073/pnas. 0504927102.

40. Ferrero RL, Cussac V, Courcoux P, Labigne A. Construction of isogenic urease-negative mutants of Helicobacter pylori by allelic exchange. J Bacteriol. 1992;174:4212-7. https://doi.org/10.1128/jb.174.13.4212-4217.1992.

41. Skorko-Glonek J, Sobiecka-Szkatula A, Narkiewicz J, Lipinska B. The proteolytic activity of the HtrA (DegP) protein from Escherichia coli at low temperatures. Microbiology (Reading, Engl). 2008;154:3649-58. https://doi. org/10.1099/mic.0.2008/020487-0.

42. Zarzecka U, Modrak-Wojcik A, Bayassi M, Szewczyk M, Gieldon A, Lesner A et al. Biochemical properties of the HtrA homolog from bacterium Stenotrophomonas maltophilia. Int J Biol Macromol. 2018;109:992-1005. https://doi.org/10.1016/j.ijbiomac.2017.11.086.

43. Lipinska B, Zylicz M, Georgopoulos C. The HtrA (DegP) protein, essential for Escherichia coli survival at high temperatures, is an endopeptidase. J Bacteriol. 1990;172:1791-7.

44. Moonens K, Hamway $Y$, Neddermann M, Reschke M, Tegtmeyer N, Kruse T, et al. Helicobacter pylori adhesin HopQ disrupts trans dimerization in human CEACAMs. EMBO J. 2018. https://doi.org/10.15252/embj.201798665.

45. Neddermann M, Backert S. How many protein molecules are secreted by single Helicobacter pylori cells: quantification of serine protease HtrA. Cell Microbiol. 2019;21:e13022. https://doi.org/10.1111/cmi.13022.

46. Albrecht N, Tegtmeyer N, Sticht H, Skórko-Glonek J, Backert S. Aminoterminal processing of Helicobacter pylori serine protease HtrA: role in Oligomerization and activity regulation. Front Microbiol. 2018;9:642. https:// doi.org/10.3389/fmicb.2018.00642. 
47. Harrer A, Boehm M, Backert S, Tegtmeyer N. Overexpression of serine protease HtrA enhances disruption of adherens junctions, paracellular transmigration and type IV secretion of CagA by helicobacter pylori. Gut Pathog. 2017:9:40. https://doi.org/10.1186/s13099-017-0189-6.

48. Harrer A, Bücker R, Boehm M, Zarzecka U, Tegtmeyer N, Sticht H, et al. Campylobacter jejuni enters gut epithelial cells and impairs intestinal barrier function through cleavage of occludin by serine protease HtrA. Gut Pathog. 2019;11:4. https://doi.org/10.1186/s13099-019-0283-z.

49. Boehm M, Hoy B, Rohde M, Tegtmeyer N, Bæk KT, Oyarzabal OA, et al. Rapid paracellular transmigration of Campylobacter jejuni across polarized epithelial cells without affecting TER: role of proteolytic-active HtrA cleaving E-cadherin but not fibronectin. Gut Pathog. 2012;4:3. https://doi.org/10. 1186/1757-4749-4-3.

50. Löwer M, Weydig C, Metzler D, Reuter A, Starzinski-Powitz A, Wessler S, Schneider G. Prediction of extracellular proteases of the human pathogen Helicobacter pylori reveals proteolytic activity of the Hp1018/19 protein HtrA. PLoS One. 2008;3:e3510. https://doi.org/10.1371/journal.pone.0003510.

51. Donczew R, Makowski Ł, Jaworski P, Bezulska M, Nowaczyk M, ZakrzewskaCzerwińska J, Zawilak-Pawlik A. The atypical response regulator HP1021 controls formation of the Helicobacter pylori replication initiation complex. Mol Microbiol. 2015;95:297-312. https://doi.org/10.1111/mmi.12866.

52. Tegtmeyer N, Rivas Traverso F, Rohde M, Oyarzabal OA, Lehn N, SchneiderBrachert W, et al. Electron microscopic, genetic and protein expression analyses of Helicobacter acinonychis strains from a Bengal tiger. PLoS One. 2013;8:e71220. https://doi.org/10.1371/journal.pone.0071220.

53. Kedzierska S, Matuszewska E. The effect of co-overproduction of DnaK/ DnaJ/GrpE and ClpB proteins on the removal of heat-aggregated proteins from Escherichia coli DeltaclpB mutant cells--new insight into the role of Hsp70 in a functional cooperation with Hsp100. FEMS Microbiol Lett. 2001; 204:355-60. https://doi.org/10.1111/j.1574-6968.2001.tb10910.x.

54. Klein G, Walczak R, Krasnowska E, Blaszczak A, Lipińska B. Characterization of heat-shock response of the marine bacterium Vibrio harveyi. Mol Microbiol. 1995;16:801-11. https://doi.org/10.1111/j.1365-2958.1995.tb02441.x.

55. Clausen T, Southan C, Ehrmann M. The HtrA family of proteases: implications for protein composition and cell fate. Mol Cell. 2002;10:443-55.

56. Chang J-Y, Li L. The unfolding mechanism and the disulfide structures of denatured lysozyme. FEBS Lett. 2002;511:73-8.

57. Sánchez-Delgado J, García-Iglesias P, Castro-Fernández M, Bory F, Barenys M, Bujanda L, et al. High-dose, ten-day esomeprazole, amoxicillin and metronidazole triple therapy achieves high Helicobacter pylori eradication rates. Aliment Pharmacol Ther. 2012;36:190-6. https://doi.org/10.1111/j.1365-2036.2012.05137.x.

58. Nishizawa T, Suzuki H. Mechanisms of helicobacter pylori antibiotic resistance and molecular testing. Front Mol Biosci. 2014;1:19. https://doi.org/ 10.3389/fmolb.2014.00019.

59. Olekhnovich IN, Vitko S, Valliere M, Hoffman PS. Response to metronidazole and oxidative stress is mediated through homeostatic regulator HsrA (HP1043) in Helicobacter pylori. J Bacteriol. 2014;196:729-39. https://doi.org/ 10.1128/JB.01047-13.

60. Azam A, Peerzada MN, Ahmad K. Parasitic diarrheal disease: drug development and targets. Front Microbiol. 2015;6:1183. https://doi.org/10.3389/fmicb.2015.01183.

61. Azzam ME, Algranati ID. Mechanism of puromycin action: fate of ribosomes after release of nascent protein chains from polysomes. Proc Natl Acad Sci U S A. 1973;70:3866-9.

62. Salomons FA, Menéndez-Benito V, Böttcher C, McCray BA, Taylor JP, Dantuma NP. Selective accumulation of aggregation-prone proteasome substrates in response to proteotoxic stress. Mol Cell Biol. 2009;29:1774-85. https://doi.org/10.1128/MCB.01485-08.

63. Tegtmeyer N, Moodley Y, Yamaoka Y, Pernitzsch SR, Schmidt V, Traverso FR, et al. Characterisation of worldwide Helicobacter pylori strains reveals genetic conservation and essentiality of serine protease HtrA. Mol Microbiol. 2016;99:925-44. https://doi.org/10.1111/mmi.13276.

64. Backert S, Tegtmeyer N. Type IV Secretion and signal transduction of Helicobacter pylori CagA through interactions with host cell receptors. Toxins (Basel) 2017. doi:https://doi.org/10.3390/toxins9040115.

65. Skorko-Glonek J, Figaj D, Zarzecka U, Przepiora T, Renke J, Lipinska B. The extracellular bacterial HtrA proteins as potential therapeutic targets and vaccine candidates. Curr Med Chem. 2017;24:2174-204. https://doi.org/10. 2174/0929867323666161223145825.

66. Zhang L, Li Y, Wen Y, Lau GW, Huang X, Wu R, et al. HtrA is important for stress resistance and virulence in Haemophilus parasuis. Infect Immun. 2016; 84:2209-19. https://doi.org/10.1128/IAl.00147-16.
67. Huston WM, Swedberg JE, Harris JM, Walsh TP, Mathews SA, Timms P. The temperature activated HtrA protease from pathogen Chlamydia trachomatis acts as both a chaperone and protease at 37 degrees C. FEBS Lett. 2007;581: 3382-6. https://doi.org/10.1016/j.febslet.2007.06.039.

68. Wenta T, Zurawa-Janicka D, Rychlowski M, Jarzab M, Glaza P, Lipinska A, et al. $\mathrm{HtrA3}$ is a cellular partner of cytoskeleton proteins and TCP1a chaperonin. J Proteome. 2018;177:88-111. https://doi.org/10.1016/j.jprot.2018.02.022.

69. Kooistra J, Milojevic J, Melacini G, Ortega J. A new function of human HtrA2 as an amyloid-beta oligomerization inhibitor. J Alzheimers Dis. 2009;17:28194. https://doi.org/10.3233/JAD-2009-1037.

70. Chien J, Ota T, Aletti G, Shridhar R, Boccellino M, Quagliuolo L, et al. Serine protease $\mathrm{HtrA} 1$ associates with microtubules and inhibits cell migration. Mol Cell Biol. 2009;29:4177-87. https://doi.org/10.1128/MCB.00035-09.

71. Poepsel S, Sprengel A, Sacca B, Kaschani F, Kaiser M, Gatsogiannis C, et al. Determinants of amyloid fibril degradation by the PDZ protease HTRA1. Nat Chem Biol. 2015;11:862-9. https://doi.org/10.1038/nchembio.1931.

72. Wenta T, Jarzab M, Rychlowski M, Borysiak M, Latala A, Zurawa-Janicka D, et al. Cellular substrates and pro-apoptotic function of the human HtrA4 protease. J Proteome. 2019;209:103505. https://doi.org/10.1016/j.jprot.2019.103505.

73. Padmanabhan N, Fichtner L, Dickmanns A, Ficner R, Schulz JB, Braus GH. The yeast HtrA orthologue $\mathrm{Ynm} 3$ is a protease with chaperone activity that aids survival under heat stress. Mol Biol Cell. 2009;20:68-77. https://doi.org/ 10.1091/mbc.e08-02-0178.

74. Francesco VD, Zullo A, Hassan C, Giorgio F, Rosania R, lerardi E. Mechanisms of Helicobacter pylori antibiotic resistance: an updated appraisal. World J Gastrointest Pathophysiol. 2011;2:35-41. https://doi.org/10.4291/wjgp.v2.i3.35.

75. Skorko-Glonek J, Zurawa-Janicka D, Koper T, Jarzab M, Figaj D, Glaza P, Lipinska B. HtrA protease family as therapeutic targets. Curr Pharm Des. 2013;19:977-1009

76. Olivera-Severo D, Uberti AF, Marques MS, Pinto MT, Gomez-Lazaro M, Figueiredo C, et al. A new role for Helicobacter pylori urease: contributions to angiogenesis. Front Microbiol. 2017;8:1883. https://doi.org/10.3389/fmicb. 2017.01883.

77. Koch KN, Hartung ML, Urban S, Kyburz A, Bahlmann AS, Lind J, et al. Helicobacter urease-induced activation of the TLR2/NLRP3/LL-18 axis protects against asthma. J Clin Invest. 2015;125:3297-302. https://doi.org/10.1172/JCI79337.

78. Valenzuela-Valderrama M, Cerda-Opazo P, Backert S, González MF, CarrascoVéliz N, Jorquera-Cordero C, et al. The Helicobacter pylori urease virulence factor is required for the induction of hypoxia-induced factor-1a in gastric cells. Cancers (Basel). 2019. https://doi.org/10.3390/cancers11060799.

79. Brisslert M, Enarsson K, Lundin S, Karlsson A, Kusters JG, Svennerholm A-M, et al. Helicobacter pylori induce neutrophil transendothelial migration: role of the bacterial HP-NAP. FEMS Microbiol Lett. 2005;249:95-103. https://doi. org/10.1016/j.femsle.2005.06.008.

80. Ricci V, Giannouli M, Romano M, Zarrilli R. Helicobacter pylori gammaglutamyl transpeptidase and its pathogenic role. World J Gastroenterol. 2014;20:630-8. https://doi.org/10.3748/wjg.v20.i3.630.

81. Allan E, Mullany P, Tabaqchali S. Construction and characterization of a Helicobacter pylori clpB mutant and role of the gene in the stress response. J Bacteriol. 1998;180:426-9.

82. Homuth G, Domm S, Kleiner D, Schumann W. Transcriptional analysis of major heat shock genes of Helicobacter pylori. J Bacteriol. 2000;182:425763. https://doi.org/10.1128/jb.182.15.4257-4263.2000.

83. Yokota K, Hirai Y, Haque M, Hayashi S, Isogai H, Sugiyama T, et al. Heat shock protein produced by Helicobacter pylori. Microbiol Immunol. 1994;38: 403-5. https://doi.org/10.1111/j.1348-0421.1994.tb01799.x.

84. Spohn G, Delany I, Rappuoli R, Scarlato V. Characterization of the HspRmediated stress response in Helicobacter pylori. J Bacteriol. 2002;184:292530. https://doi.org/10.1128/jb.184.11.2925-2930.2002.

85. Gur E, Sauer RT. Recognition of misfolded proteins by Lon, a AAA+ protease. Genes Dev. 2008;22:2267-77. https://doi.org/10.1101/gad.1670908.

86. Schmidt TP, Perna AM, Fugmann T, Böhm M, Jan H, Haller S, et al. Identification of E-cadherin signature motifs functioning as cleavage sites for Helicobacter pylori HtrA. Sci Rep. 2016;6:23264. https://doi.org/10.1038/srep23264.

87. Schmidt TP, Goetz C, Huemer M, Schneider G, Wessler S. Calcium binding protects E-cadherin from cleavage by Helicobacter pylori HtrA. Gut Pathog. 2016;8:29. https://doi.org/10.1186/s13099-016-0112-6.

\section{Publisher's Note}

Springer Nature remains neutral with regard to jurisdictional claims in published maps and institutional affiliations. 